\title{
Incomplete Immune Recovery in HIV Infection: Mechanisms, Relevance for Clinical Care, and Possible Solutions
}

\author{
Julie C. Gaardbo, Hans J. Hartling, Jan Gerstoft, and Susanne D. Nielsen \\ Department of Infectious Diseases, Rigshospitalet, University Hospital of Copenhagen, 2100 Copenhagen, Denmark \\ Correspondence should be addressed to Susanne D. Nielsen, sdn@dadlnet.dk
}

Received 24 November 2011; Accepted 22 December 2011

Academic Editor: Carlo Torti

Copyright ( $) 2012$ Julie C. Gaardbo et al. This is an open access article distributed under the Creative Commons Attribution License, which permits unrestricted use, distribution, and reproduction in any medium, provided the original work is properly cited.

\begin{abstract}
Treatment of HIV-infected patients with highly active antiretroviral therapy (HAART) usually results in diminished viral replication, increasing CD4+ cell counts, a reversal of most immunological disturbances, and a reduction in risk of morbidity and mortality. However, approximately $20 \%$ of all HIV-infected patients do not achieve optimal immune reconstitution despite suppression of viral replication. These patients are referred to as immunological nonresponders (INRs). INRs present with severely altered immunological functions, including malfunction and diminished production of cells within lymphopoetic tissue, perturbed frequencies of immune regulators such as regulatory $\mathrm{T}$ cells and Th17 cells, and increased immune activation, immunosenescence, and apoptosis. Importantly, INRs have an increased risk of morbidity and mortality compared to HIV-infected patients with an optimal immune reconstitution. Additional treatment to HAART that may improve immune reconstitution has been investigated, but results thus far have proved disappointing. The reason for immunological nonresponse is incompletely understood. This paper summarizes the known and unknown factors regarding the incomplete immune reconstitution in HIV infection, including mechanisms, relevance for clinical care, and possible solutions.
\end{abstract}

\section{Introduction}

Treatment of HIV infection with highly active antiretroviral therapy (HAART) usually results in diminished viral replication and increasing CD4+ cell counts. When HAART is initiated, a biphasic response occurs with an initial high increase in CD4+ cells primarily due to reduced apoptosis and redistribution of memory CD4+ cells from lymphoid tissue, followed by a slower on-going increase in part generated from production of naïve CD4+ cells $[1,2]$. For how long this increase proceeds is debatable, but cohort studies suggest CD4+ cell recovery for at least 5 years of HAART as long as the CD4+ cell count is $<500$ cells $/ \mu \mathrm{L}$ [3]. However, approximately $20 \%$ of all HIV-infected individuals fail to restore their CD4+ cell counts despite optimal treatment and fully suppressed viral replication $[2,4,5]$. These individuals are referred to as immunological nonresponders (INRs).

The definition of INR suffers from lack of consensus impeding the comparison of findings. Most often INRs are defined as having CD4+ cell counts $<200$ cells/ $\mu \mathrm{L}$ while the treatment duration needed for categorizing patients as INR is variable. Furthermore, some study groups define INR by the CD4+ cell increase in percentages, most commonly $<20 \%$ increase from baseline [6-9]. On the other hand, there seems to be agreement that an adequate immune response to HAART should include a CD4+ cells count $>500$ cells $/ \mu \mathrm{L}$, mainly because HIV-infected patients with this level of immune restoration have a morbidity and mortality rate approaching or comparable to those of HIV negative individuals [10]. Patients with CD4+ cell counts $<500$ cells $/ \mu \mathrm{L}$ are consequently classified as inadequate responders. Inadequate responders are a heterogeneous population since INR is included within this group of patients. Thus, a large group of inadequate responders, those with intermediate response with CD4+ cells counts between 200 and 500 cells $/ \mu \mathrm{L}$, are poorly described, although they may have a morbidity and mortality rate distinct from INR as well as from those with adequate immune response [11]. In contrast, the increased risk of long-term morbidity and mortality in INR is widely accepted [11-13]. This demonstrates an obvious reason for 
delineating the cause of the poor immunological response seen in INR. It also emphasizes the need for additional treatment strategies for HAART. The scope of this paper is to focus on the immunological explanations for immunological nonresponse in patients with full virological responses, clinical relevance, and feasible solutions.

\section{Explanations of Immunological Nonresponse}

INR has been associated with a number of factors. Thus, it has been shown that older age, a long duration of the HIV infection prior to HAART, coinfection with hepatitis $\mathrm{C}$, and a low CD4 nadir predispose to immunological nonresponse [13-17]. The CD4 nadir specifically appears to be critical for the recovery of CD4+ cells $[14,15]$. However, none of these factors provide a full explanation for the lack of immune reconstitution in INR. As a result of this, immunological explanations have been proposed.

The CD4+ cell count in a given patient at any time is the result of production, destruction, and traffic between blood and lymphatic tissue. Thus, if the destruction exceeds the production, the CD4+ cell count decreases. INR may have alterations in the production of CD4+ cells resulting in a reduction of output as well as a destruction of CD4+ cells resulting in an increased turnover. Finally, the distribution of cells between blood and lymphatic tissue may be different in INR.

\section{Production of CD4+ Cells}

3.1. Thymus and Naive Cells. CD4+ cells are created from already existing $\mathrm{CD} 4+$ cells by proliferation, or they are produced in the thymus. The genesis of the T-cell receptor (TCR) takes place in the thymus only, and CD4+ cells generated in the thymus lead to immune reconstitution with a pool of CD4+ cells with full immunologic repertoire $[1$, 18]. Furthermore, HIV-infected patients with a large thymus have a better immune reconstitution and a broader immunological repertoire than patients with a small thymus $[19,20]$. The thymus was thought to be only active in childhood; however it is replaced by fatty tissue with increase in age. It is now evident that the thymus can also be active in adulthood, particularly during circumstances with lymphopenia, as is the case with HIV infection $[21,22]$. Thymic tissue has been visualized on computed tomography (CT) scans in HIVinfected adults, and the size of the thymus has been shown to be positively associated with naive CD4+ cell counts and total CD4+ cell counts $[19,23,24]$. However, the performance of CT scans is neither practical nor economically responsible in HIV-infected patients, and often thymic function is assessed indirectly as T-cell receptor excision circles (TRECs), as recent thymic emigrants (RTEs), or simply as the naive CD4+ cell count. TRECs are stable circular DNA fragments that are excised during the formation of TCR in the maturing $\mathrm{T}$ cell in the thymus, and TRECs are not replicated during cell division. Thus, the more immature CD4+ cells, the higher the TREC content. A large thymus on CT scans has been associated with a higher CD4+ TREC frequency in HIV-infected patients [19]. During the maturation process,
$\mathrm{T}$ cells emigrate from the thymus into the periphery now classified as RTE [25], and after further maturation RTEs are classified as naive T cells. Thus, TRECS, RTEs and naive cells are all reasonable indirect measurements of thymic output, although the number of naive cells may be the result of thymic output as well as peripheral proliferation.

Thymic output is dramatically reduced with age, and the naïve cells are increasingly generated from proliferation (reviewed in [26]). RTEs express the surface marker platelet endothelial cell adhesion molecule-1 (PECAM-1) also known as CD31 $[27,28]$. Proliferation leads to loss of CD31 and a lower TREC count, and therefore naïve cells in older individuals have decreasing proportions of CD31 and lower TREC counts [27, 28]. HIV leads to a disruption in the number and function of naïve $\mathrm{CD} 4+$ cells in blood as well as in lymphoid tissue $[5,29,30]$. After initiation of HAART, thymic output and the total numbers of naïve cells increase to subnormal levels, while the naïve T-cell proliferation decreases [5, 29-31]. Even 7 years of HAART rarely normalizes the naïve $\mathrm{CD} 4+$ cell counts to preinfection levels [32]. The naïve compartment in INR seems to be even more perturbed than in HIV-infected patients with a better immune reconstitution. Thus, one study found no residual thymic tissue on CT and PET scans in INR [33]. The same study found low, though detectable, thymopoiesis assessed as circulating RTE. In support of this, other studies have found decreased levels of naïve $\mathrm{T}$ cells and $\mathrm{T}$ cells expressing CD28 in INR [7, 34], suggesting an altered thymopoiesis in INR. The assumption that peripheral proliferation is a compensatory mechanism to altered thymopoesis in INR is supported by the finding of increased proportions of the peripheral proliferation marker Ki67 in INR, although the same study found similar levels of RTE in INR versus normal responders [35]. Similar levels of TREC in INR and normal responders have also been reported [36]. It is not known if a small thymus is predictive of INR. However, in a prospective study of $30 \mathrm{HIV}$-infected individuals, thymic CT scans were obtained to investigate the role of the thymus in cellular restoration after initiation of HAART. Individuals with abundant thymic tissue had higher naive CD4+ cell counts at weeks 2-24 than individuals with minimal thymic tissue [24]. Likewise, a large thymus has been shown to be associated with better immune reconstitution in other studies $[23,37]$.

Another way to assess factors influencing the capability to produce CD4+ cells is to examine the response to treatment interruption. Thus, it has been demonstrated that a small thymic volume and a low level of memory $\mathrm{CD} 4+$ cells predict a faster loss of $\mathrm{CD} 4+$ cells during treatment interruption $[38,39]$. This supports thymopoiesis as being essential in immune reconstitution. Interestingly, a newly published prospective study of thymectomized children showed that thymic tissue could be identified on magnetic resonance imaging scans in the majority of these children later on in life [40]. This highlights the great plasticity of the normal immune system, and together with the aforementioned findings it substantiates the evidence for permanent damage on the thymic tissue in INR (Figure 1). 


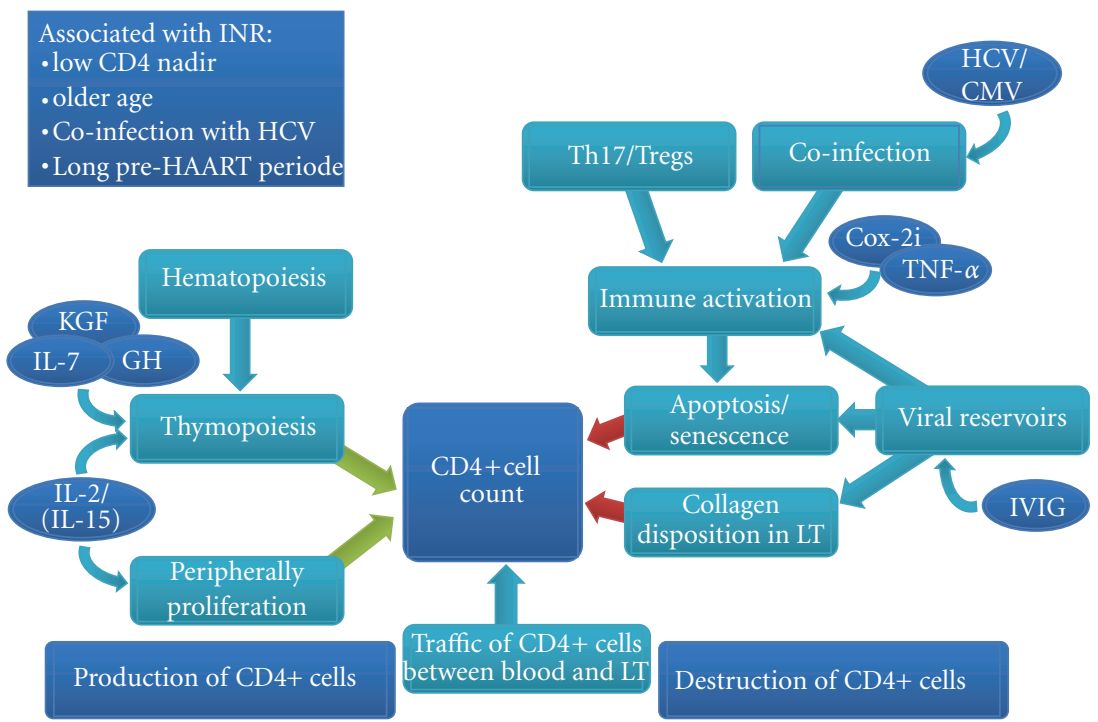

Figure 1: Factors influencing CD4+ cell count (LT: lymphatic tissue).

3.2. Bone Marrow and Progenitor Cells. T cells mature in the thymus, but they originate from hematopoietic progenitor cells (HPCs) in the bone marrow (BM). Thus, a functional $\mathrm{BM}$ is crucial for thymopoiesis and possibly for immune reconstitution. Recently, HPC has been given much attention in the hopes of realizing a functional cure for HIV infection, more relevant than ever after the newly published report of eradication of HIV by transplantation of CCR5-deficient HPC in the so-called Berlin-patient [41]. HIV influences $\mathrm{BM}$ and HPC. First of all, impaired hematopoiesis in HIV infection has been shown in a number of studies [4244]. Secondly, several studies have shown that a proportion of HPCs express the HIV receptors CD4, CXCR4, and CCR5 making them potentially susceptible to HIV infection (reviewed in [45]). Recently, infection of HPC with HIV was suggested [46], although it has been difficult to determine if these HPCs are actually infected according to the complexities of purifying and maintaining HPC in culture. Also, measurements of infection may be confounded by contamination with other cell types or maturation of HPC to monocytes during in vitro culture. Furthermore, like T cells, natural killer cells and B cells, including naïve B cells, seem to be depleted during HIV infection [47]. HIV-associated lymphopenia may therefore be explained by more upstream elements of lymphocyte development than reduced thymic output. In a study of BM from 12 INR compared to normal responders, an altered cytokine production was found, and a reduced growth of in vitro colonies was shown [34], suggesting impaired hematopoiesis as a contributing factor to poor immune reconstitution. However, studying the HPC is limited by the poor access to BM, and since HPCs enter the circulation [48], most studies are conducted on circulating HPC in the peripheral blood. Circulating HPCs have been found to decrease with disease progression and to be associated with CD4+ cell count [49], supporting the idea of BM and HPC as being essential in immunological reconstitution. This is further supported by in vitro studies, which has shown that treatment with the hematopoietic growth factor granulocyte-colony-stimulating factor (GCSF) causes an increase in the numbers of circulating CD4+ cells [50]. Others have found that peripheral mononuclear blood cells (PBMCs) from HIV-infected patients placed on fetal thymus lobes from mice produced fewer CD4+ and CD8+ cells compared with PBMCs from uninfected controls. Also, fewer functional precursors in the HIVinfected patients were found [51]. This is consistent with a loss in the capacity of HIV-infected patients to produce functional T-cell progenitors in their peripheral blood. Thus, in theory dysfunctional BM and HPC might contribute to immunological nonresponse. However, so far very few studies have validated the number or function of HPC in patients with poor immune reconstitution.

3.3. Cytokines. Interleukin 7 (IL-7) is crucial in the Tcell homeostasis, and the IL-7 responsiveness is determined largely by the presence or absence of the IL-7 receptor (IL$7 \mathrm{R}$ ) which is present on most mature T cells [52]. Furthermore, IL-7 is a modulator of peripheral T-cell homeostasis involved in maintaining the naïve T-cell pool by promoting their survival and inducing proliferation without switching naïve phenotype [53]. A negative correlation between IL7 and CD4+ cell count is described. Consequently, HIVinfected patients show high levels of IL-7 and reduced levels of IL-7R compared to healthy controls [54, 55], consistent with the need for increased production of CD4+ cells and a downregulation of the receptor due to high plasma levels. A study found that a reduction of naive CD4+ cells in INR was associated with a reduced expression of IL-7R and in increased serum levels of IL-7 [6]. In addition, a higher stromal production of IL-7 in INR compared to normal responders has been observed $[34,56]$. Considering IL-7 as an inducer of $\mathrm{CD} 4+$ cell production, these findings are not 
surprising in patients with a low CD4+ cell count. However, the interesting conclusion in relation to INR might be that the source of the CD4+ cells is impaired in INR, not the signals.

Like IL-7, interleukin 2 (IL-2) and interleukin 15 (IL15), which are part of the gamma-chain cytokine family, are central regulators of $\mathrm{T}$-cell proliferation, activation, and differentiation as well (reviewed in [57]). In contrast to IL-7, the production of IL-2 and IL-15 is compromised in HIVinfected patients (reviewed in [58] and [59]). Moreover, the production of IL-2 in blood from INR stimulated with phytohaemagglutinin has been shown to be decreased compared to HIV-infected patients with higher CD4+ cell counts [7]. Thus, in theory improving the regulation of IL2 and IL-15 in HIV-infected patients might be beneficial as discussed later.

\section{Destruction of CD4+ Cells}

4.1. Immune Activation. Immune activation (IA) in the natural history of HIV infection covers a broad spectrum of cellular processes. Untreated HIV-infected patients display elevated markers of activation in most cell compartments, especially expression of the surface markers CD38 and HLADR on T cells [60-64]. Also, high levels of proinflammatory cytokines such as tumor necrosis factor alpha (TNFa), interleukin 6 (IL-6), and interleukin 1b (IL-1b) have been shown in plasma as well as in lymph nodes [65-68]. IA usually reflects a normal and healthy response upon infection with any pathogen, including HIV, as an effort to evade infection. However, it is well established that IA is linked to and predictive of disease progression, and IA has an additive or stronger prognostic value than does CD4+ cell count or viral load alone [60-64, 69-71]. This is highlighted by the fact that a rare subgroup of HIV-infected patients, elite controllers, who do not progress, and sustain normal CD4+ cell counts and undetectable viral loads despite lack of treatment have a lower IA than normal progressors do [72]. Also, the natural hosts of simian immunodeficiency virus (SIV), sooty mangabeys and African green monkeys, do not show any signs of increased IA, T cell turnover, or disease progression $[73,74]$. Thus, IA is a key feature in HIV infection and disease progression, elegantly supported by the fact that rats develop pneumocystic pneumonia solely as a consequence of IA [75].

The reason for the strong predictive value of IA in HIV infection is uncertain. In the setting of untreated HIV infection, the level of IA might be determinant for how fast the turnover of $\mathrm{T}$ cells is, thereby being related to exhaustion. Indeed, it has been proposed that IA leads to CD4+ cell depletion because it erodes the naïve T-cell pool [76]. However, untreated and treated HIV infection are two different settings. IA declines when HAART is initiated, although like most other immunological parameters, it is not normalized [77-79]. IA is one of the best valued immunological features in INR, and a number of studies have shown elevated IA in INR compared to HIV-infected patients with a better immunological recovery $[6,7,35,80]$. Assuming INR to have a dysfunctional immune system, the high level of IA could be a consequence of rather than a reason for poor immune reconstitution. Lack of association between the extent of CD4+ cell recovery and activation of CD8+ cells beyond the first year of successful HAART [81] as well as the opposite has been found [78]. Either way, it does not answer the question whether the increased IA is the result of more upstream deficits. Finally, increased IA during primary HIV infection has been proposed to be predictive of CD4+ cell depletion and poor response to HAART [82], suggesting that preinfection host factors may predict poor immune reconstitution.

Another aspect is the findings of an overweight of residual viremia detected by ultrasensitive assays in INR, which seems to be linked to IA [83]. This might reflect release of archived viruses from cellular reservoirs and might be a contributing factor to the higher levels of IA found in INR. Also, one study reports a higher frequency of CXCR4 virus in INR. They suggest X4 virus as players in the depletion of naïve T cells in INR by triggering persistent IA and bystander apoptosis via gp120-CXCR4 interactions [84], suggesting the coreceptor dominance to be involved in the level of immune reconstitution. Moreover, it is acknowledged that CCR5 virus dominates early in infection, while X4 dominance appears later on, and increased thymic destruction has been associated with X4 viruses (reviewed in [85]).

4.2. Apoptosis and Senescence. Although the plasticity and capacity for regeneration of the immune system is prodigious, it may have boundaries. Thus, it becomes increasingly plausible that a cell can undergo a limited number of divisions and in the end will be trapped in growth arrest and immunological senescence, referred to as the Hayflick limit (reviewed in [86]). In the setting of HIV infection, this becomes relevant due to the increased production and turnover of cells. A possible way to determine the replicative history is to measure the length of the telomeres, which shorten by every cell division. The enzyme telomerase can compensate for this shortening, and indeed HIV-infected patients have been found to have shorter telomere length and dysregulated telomerase activity [87-89]. Short telomeres can lead to chromosome instability, involving growth arrest and apoptosis. Thus, not surprisingly HIV-infected patients present with elevated levels of apoptosis [90], and both early and late apoptotic CD4+ cells are more prevalent in patients with CD4+ cell counts $<500$ cells/ $\mu \mathrm{L}$ [90-94]. The relevance of markers of immune exhaustion and senescence in relation to immune reconstitution is confirmed by the findings of the expression of the activation associated $\mathrm{T}$ cell molecule programmed death-1 (PD-1). PD-1 conveys inhibitory signals to $\mathrm{T}$ cells (reviewed in [95]), and PD-1 is selectively upregulated by exhausted $\mathrm{T}$ cells during chronic viral infection [96]. Elevated levels of PD-1 in INR compared to normal responders have been reported [80, 97]. Also, PD1 expression has been shown to be negatively correlated to CD4+ cell count, and PD-1 expressing T cells are more prone to programmed cell death ligand-mediated inhibition of $\mathrm{T}$ cell proliferation [97].

Finally, chronic infection with cytomegalovirus (CMV) has been associated with immunological senescence, and 
a high proportion of $\mathrm{T}$ cells specific for CMV and CMVviremia is associated with a low CD4+ cell count and increased mortality ([98], reviewed in [99]).

4.3. Pro- and Anti-Inflammatory $T$ Cells. During recent years, the understanding of immune responses has changed tremendously by the discovery of T-cell subsets with proand anti-inflammatory properties. Th17 cells are T cells with proinflammatory properties, while regulatory $\mathrm{T}$ cells (Tregs) are anti-inflammatory. Tregs play a crucial role in sustaining tolerance to self-antigens $[100,101]$ and suppressing Tcell activation resulting in downregulation of immune activation, including reduction in antitumor immunity, graft rejection, and graft-versus-host disease ([102], reviewed in [103]). Finally, the role of Tregs in chronic viral infections, including HIV, has gained massive interest due to their immunosuppressive capabilities. Tregs themselves are CD4+ cells and susceptible to HIV infection [104]. Therefore, the absolute number of Tregs declines with disease progression, while the frequency of Tregs tends to increase and remains high on HAART [105-108]. Thus, in a prospective study Tregs were measured in 26 HIV-infected patients before and after HAART and compared to healthy controls. The level of Tregs was found to be elevated in patients compared to controls, and this level did not change despite 6 months of HAART [106]. Tregs are believed to be able to downregulate chronic immune activation in HIV infection making Tregs a key element in the understanding of the interaction between the host immune system and HIV (reviewed in [109]). However, Tregs might be beneficial as downregulators of the unbeneficial immune activation or, in contrast, they might have a harmful effect downregulating HIV-specific responses. So far, it is not clear whether Tregs accelerate or delay HIV infection.

IL-17-producing Th17 cells are closely related to Tregs. Th17 cells and Tregs share a reciprocal maturation pathway and function together in opposing ways to control the inflammatory response to infection. While Tregs inhibit autoimmunity, Th17 cells play a role in the induction of autoimmune tissue injury [110]. During acute SIV infection the rapid depletion of Th17 cells and a disturbed balance of Th17 cells and Tregs are associated with subsequent high IA and disease progression [111]. Likewise, in HIV-infection the loss of balance between Th17 cells/Tregs may play a part in inducing microbial translocation and chronic immune activation [112] (reviewed in [113]). The importance of a well-regulated balance between Tregs and Th17 cells is demonstrated by a maintained balance between Tregs and Th17 cells in HIV controllers [114] (reviewed in [115]). Finally, recent data from our own lab show disturbances in the Treg- and Th17 cell compartments as well as in the balance between them in INR, suggesting an impact on immune reconstitution [116].

4.4. Secondary Lymphatic Tissue. CD4+ cell depletion occurs in the blood as well as in the secondary lymphatic tissue (SLT) of lymph nodes (LNs) and gut-associated lymphatic tissue (GALT) where the majority of the CD4+ cells reside. A vast number of cells are lost during primary infection, and by the time the infection has reached a chronic stage; more than $50 \%$ of the CD4+ cells in the LN are lost $[117,118]$. With a possible damage of primary lymphatic tissue (LT) (i.e., thymic tissue and bone marrow) in mind, it seems reasonable to consider damages to SLT as a consequence of HIV infection as well, suggesting this early massive depletion as a determinant for the level of immune reconstitution following HAART. Thus, it has been proposed that HIV damages the structures in the lymphatic tissue that help sustain the normal CD4+ cell population, replacing the functional space with collagen. It was found that the greater the amount of the collagen-deposition, the lower the CD4+ cell count, and the smaller the number of naive CD4+ cells [119]. Furthermore, the amount of the collagen-deposition in $\mathrm{LN}$ has proven to be predictive for the degree of the immune reconstitution [120]. Also, LN biopsies from HIV and SIV-infected individuals show breakdown of the lymph node architecture and evidence of apoptosis [121].

These findings are consistent with HIV as a causative agent in damage to SLT. In light of this, it is worth noticing that SLT serves as viral reservoirs, including a pool of latently infected, resting CD4+ cells, which is believed to be a major impediment to the eradication of HIV [122]. While HAART rapidly reduces viral load in the blood, viral production is still detectable in SLT $[123,124]$, and it would be interesting to ascertain whether the pool of latently infected cells influences immune reconstitution. So far, it has been shown that the level of immune reconstitution is associated with certain types of cellular reservoirs. Thus, proviral DNA primarily persists in central memory cells in patients with a good immune reconstitution, while patients with a poorer reconstitution mainly host HIV proviral DNA in transitional memory cells [125]. This suggests that the viral reservoir influences immune reconstitution, and therefore it seems of interest to identify treatment strategies in addition to HAART with the ability to suppress the viral production in SLT, possibly leading to limited destruction of LT and a better immune reconstitution.

Another aspect is the fact that infection with HIV leads to redistribution of $\mathrm{CD} 4+$ cells between blood and lymphatic tissue. Thus, it has been demonstrated that HIV binds to resting CD4+ cells and upregulates L-selectin causing the cells to home from the blood into LN at enhanced rates $[126,127]$. This has lead to the homing theory, which offers an explanation for the loss of CD4+ cells due to cells leaving the blood and entering the LT (reviewed in [128]). Thus, it would be interesting to evaluate the amount of CD4+ cells outside the blood in SLT in INR, which may reveal accumulation of CD4+ cells. Indeed accumulation of Tregs has been found in SLT compared to peripheral blood in untreated HIV-infected patients [129].

\section{Clinical Implications: Relevance for Clinical Care}

Treatment with HAART reduces the risk for development of AIDS and death. Consequently, a relative increase in morbidity and mortality has been described. Despite efficient treatment with HAART and suppression of viral 
replication, HIV-infected individuals have increased risk of morbidity and mortality when compared to uninfected population controls [130]. The reason for this is multifactorial. Thus, HIV itself is the leading cause (reviewed in [131]). However, HAART has been shown to cause metabolic and atherosclerotic changes (reviewed in [132, 133]). Furthermore, lifestyle-related factors such as increased alcohol consumption, smoking, drug-abuse, and poverty are all associated with being HIV infected (reviewed in [134137]). Finally, among HIV-infected patients coinfection with hepatitis B and C is more common because hepatitis and HIV share transmission routes.

However, there are great differences in the risk of morbidity and mortality among different groups of HIV infected patients. Higher risk of opportunistic diseases and death was discovered to be associated with relative immunodeficiency in the SMART study [138], and INRs in particular have increased risk of opportunistic infections and long-term morbidity and mortality [11-13, 139]. Thus, INRs have a much higher risk of opportunistic diseases and death. In the UK CHIC study, the number of deaths/100 person years of follow-up was a hundred times higher in the group of patients with CD4+ cell counts below 50 cells $/ \mu \mathrm{L}$ compared to CD4+ cell counts above 500 cells $/ \mu \mathrm{L}$ [140]. Contrary, HIV-infected patients without risk factors and optimal response to HAART seem to have a mortality comparable to HIV negative individuals [141]. Importantly, rates of death increase substantially with declining $\mathrm{CD} 4+$ cell counts at baseline along with the extent of immunological deficiency prior to the period of sustained suppression of viral replication $[11-13,142]$. For this reason, patients diagnosed with HIV in an advanced state of the disease (HIV late-presenters) are in higher risk of being INR (reviewed in [143]). Also, the lower the CD4 nadir, the shorter it takes for the CD4+ cell count to drop during treatment interruption [144].

Non-AIDS morbidity comprises of diseases such as cardiovascular disease (CVD), cancer, renal disease, hepatic disease, and osteoporosis. Thus, HIV-infected patients suffer more from clinical as well as subclinical atherosclerotic disease compared to the general population, and atherosclerotic (CVD) is a leading cause of death in HIV-infected patients [145]. HIV infection is associated with immune activation and inflammation. Inflammation in turn may lead to vascular damage and dysfunction increasing the risk of CVD (reviewed in [146]). Furthermore, HAART may increase the risk of myocardial infarction [147]. Either way, a consistent relation between low $\mathrm{CD} 4+$ cell counts and increased risk of CVD morbidity and mortality has been shown in a number of studies (reviewed in [148]). Thus, in a cross-sectional study of 1331 HIV-infected women and 600 HIV-infected men, the subclinical carotid artery lesions and common carotid artery intima-media thickness were measured by ultrasound. A low CD4+ cell count was found to be independently associated with an increased prevalence of carotid lesions [149]. The reason for this increased risk in INR is unknown, but the increased inflammation seen in patients with poor immune reconstitution as previously described seems like a more plausible reason than does the CD4+ cell count itself.

Likewise, HIV-infected patients have increased risk of cancer compared to the general population. It is well known that initially low and decreasing CD4+ cell counts during the year prior to cancer diagnosis are predictive of AIDSdefining malignancies (ADMs) such as Kaposi sarcoma and non-Hodgkin lymphoma as shown in the CASCADE study [150]. Also, the COHERE study showed that during HAART higher CD4+ cell counts are protective for the development of non-Hodgkin lymphoma [151]. Furthermore, non-AIDSdefining malignancies (non-ADM) such as anal cancer are more common in immune compromised patients (reviewed in [152]). In the D:A:D study the relationship between deaths due to ADM and non-ADM was determined, and immunodeficiency was evaluated. In a large observational cohort study including 23, 437 patients that were followed prospectively, a low $\mathrm{CD} 4+$ cell count was found to be predictive of death from both $\mathrm{ADM}$ and non-ADM in HIV-infected patients [153]. Likewise, a low current CD4+ cell count was shown to be associated with an increased incidence of certain non-ADM by the EuroSIDA group [154]. In conclusion, as expected ADMs are closely related to the CD4+ cell count. However, non-ADMs are related to the CD4+ cell count as well, presumably due to a poor immune function, especially since one study found that $48.3 \%$ of all non-ADMs were virus related [154]. All together HIV-infected patients have increased risk of developing malignancies, and more so in the group of INR.

Finally, the HIV-associated neurocognitive disorders (HANDs) have become an area of increasing interest as HIV infected patients become older and live longer. In the CHARTER study, a cross-sectional, observational study of 1,555 HIV-infected patients on HAART, the frequency and associated features of HAND were determined. Fifty-two percent of the total sample had neuropsychological impairment with higher rates in groups with greater comorbidity burden. The lowest impairment rate occurred in patients with a CD4 nadir and a current CD4+ cell count above 200 cells $/ \mu \mathrm{L}$ [155]. In general, a history of a low CD4 nadir seems be one of the strongest predictors of impairment [155, 156]. Future studies should identify whether early disease events (e.g., profound CD4 decline) may trigger chronic CNS changes, and whether early HAART prevents or reverses these changes.

In summary, there remains no doubt that a full immunological recovery is essential in order to reduce morbidity and mortality among HIV-infected patients. However, obtaining this goal requires improving earlier diagnosis and additional treatment to HAART. Several supplementary immune-based therapies to enhance immune reconstitution are under investigation using cytokines, hormones, and growth factors.

\section{Therapeutical Possibilities}

6.1. Optimizing HAART. Optimizing HAART may be a possibility to increase CD4+ cell counts in HIV-infected INR (systematically reviewed in [157]), and recent data on new drug modalities such as CCR5-antagonists, integrase 


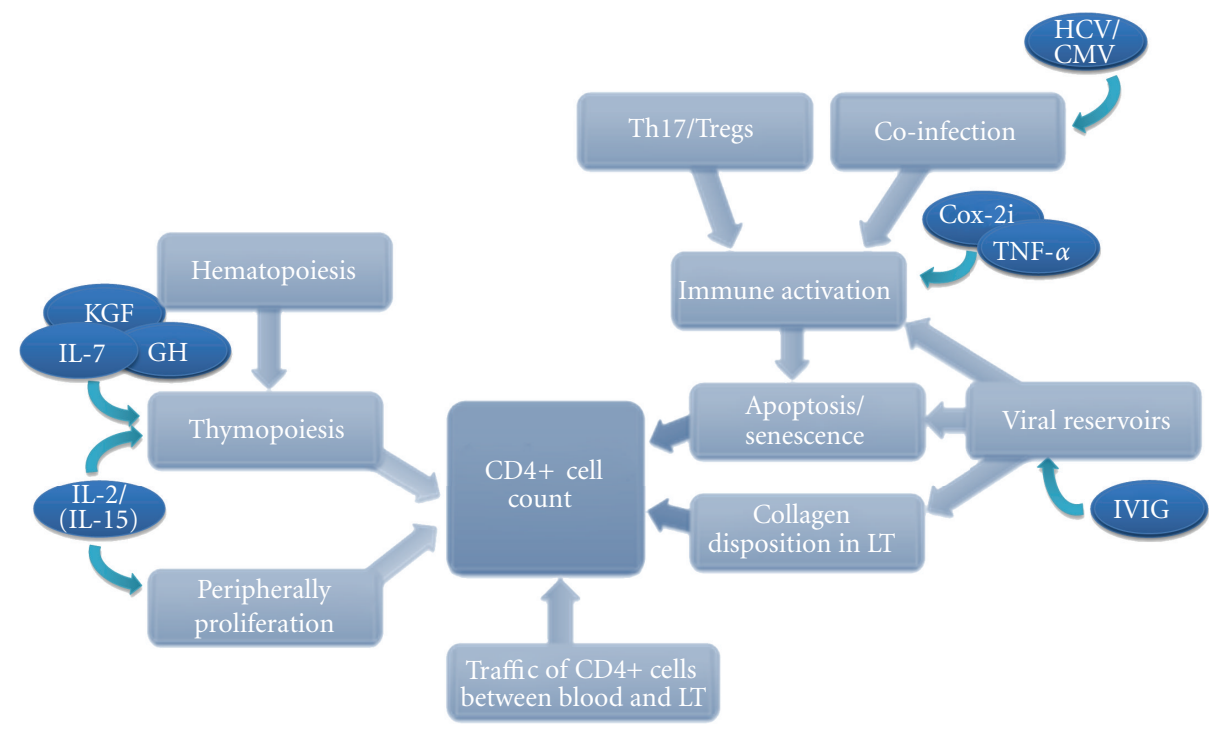

FIGURE 2: Therapeutical possibilities improving immune reconstitution. KGF: keratinocyte growth factor; IL: interleukin; GH: growth hormone; HCV/CMV: treatment of hepatitis C virus and cytomegalovirus; Cox2i: cyclooxygenase inhibitor; TNF: tumor necrosis factor; IVIG: intravenous immunoglobulin.

inhibitors, and fusion inhibitors increase the relevance of this matter. HIV uses CCR5 as a coreceptor for cell entry, which has led to development of several CCR5-antagonists to impede HIV infection. Currently, only Maraviroc is FDAapproved for treatment of HIV infection. The phase III randomized clinical MOTIVATION study demonstrated that addition of Maraviroc to HAART in pretreated patients resulted in a significant increase in CD4+ cell counts as well as reduced viral load [158]. Furthermore, administration of Maraviroc seems to result in decreased immune activation [159]. Underlining these findings, a meta-analysis of phase II/III clinical trials testing CCR5-antagonist in treatmentexperienced HIV patients demonstrated significant increase in CD4+ cell counts by adding CCR5-antagonist [160], clearly suggesting a potential of drugs targeting CCR5 for optimizing immune reconstitution in INR. Raltegravir targets the HIV integrase, which facilitates the integration of the genetic material into the hosts DNA, and is at present the only FDA-approved integrase inhibitor. The potential of raltegravir has proven effective in the large phase III BENCHMRK study [161] showing increased CD4+ cell counts and reduced viral loads. However, two randomized clinical studies testing the effect of raltegravir in INR did not demonstrate an additional effect on immune reconstitution $[162,163]$. Several clinical trials testing other integrase inhibitors are ongoing (http://www.clinicaltrials.org/), and a large phase III study comparing intensification of HAART with raltegravir and elvitegravir in treatment-experienced patients demonstrated no significant difference between the two drugs in regard with immune reconstitution [164]. Finally, enfuvirtide is the only FDA-approved fusion inhibitor. It impedes fusion of HIV to the target cell by binding to gp41. Two multicenter phase III studies (TORO $1 / 2$ ) documented an effect of enfuvirtide in combination with HAART in treatment-experienced patients on both CD4+ cell count and viral load $[165,166]$. However, a large randomized multicenter study (ANRS130) demonstrated no additional effect of supplementary enfuvirtide to HAART on CD4+ cell counts in treatment-naive late-presenters with low CD4+ cell count [167]. Thus, at present Maraviroc seems to be the most promising drug for HAART intensification. However, larger prospective studies assessing the effect in INR are needed to estimate the clinical benefits of HAART intensification (Figure 2).

6.2. Interleukin-2 (IL-2). Several strategies to improve immune reconstitution in HIV patients have been considered during the last decade. Most of these strategies aim to increase thymus activity and/or peripheral proliferation. Of all suggested strategies supplementary treatment with recombinant human (rh)IL-2 is the best described. Thus, several studies have shown that combination therapy with rhIL-2 and HAART increases CD4+ cell counts in HIV patients compared to HAART alone (reviewed in [168]). The increased level of CD4+ cells is long-lasting and is caused by peripheral proliferation, although increased thymopoiesis may contribute as well [169]. Despite increased CD4+ cell counts, supplementary treatment with rhIL-2 did not result in clinical benefit for the treated patients, which was demonstrated in two large randomized prospective clinical trials (ESPRIT, 4111 patients, and SILCAAT, 1695 patients). The ESPRIT study revealed an increased risk of grade 4 clinical event in the IL-2-treated group. However, these data did not illustrate the (adverse) effects of supplementary rhIL-2 treatment in INR as median CD4+ cell counts were $>400$ cells $/ \mu \mathrm{L}$ in the ESPRIT study, and $<200$ cells $/ \mu \mathrm{L}$ in the SILCAAT study. In fact, stratified results for patients with a CD4+ cell count $<200$ cells $/ \mu \mathrm{L}$ in the SILCAAT study showed 
a nonsignificant decreased risk of adverse effect in the IL-2 treatment arm and still a significant increase in CD4+ cell count. A small study confirmed increased CD4+ cell count in INR after supplementary rhIL-2 treatment and demonstrated enhanced immune function ex vivo [170]. Also, a higher incidence of HIV-related clinical events has been observed among INR receiving HAART alone than among subjects receiving HAART plus IL-2 [171]. In conclusion, at present supplementary rhIL-2 has no place as a therapeutic agent in the treatment of HIV infection. However, it cannot be completely ruled out that INR may benefit, but it must be considered with great caution, and further studies are warranted to conclude whether any clinical benefit exists for supplementary IL-2 treatment in INR.

6.3. IL-7. As described, IL-7 is an essential regulator of the T-cell homeostasis. Administration of rhIL-7 to HIVinfected patients is being tested in several ongoing clinical trials (clincialtrials.gov, reviewed in [172]). Animal studies [173] and phase I/II studies report that IL-7 is well tolerated, but rhIL-7 administration causes a transient increase of viral replication $[174,175]$. However, concomitant HAART counteracts this adverse effect and supplementary rhIL7 treatment has proven safe $[174,175]$. Subcutaneous administration of single dose of rhIL-7 (3-100 $\mu \mathrm{g} / \mathrm{kg})$ [174] as well as intermittent doses (3 or $10 \mu \mathrm{g} / \mathrm{kg}$ ) [175] results in significant dose-dependent increase in CD4+ cell counts. This increase includes both central memory cells and naive cells. Importantly, administration of rhIL-7 has been shown to increase levels of RTE, numbers of TRECs, as well as increase naive CD4+ cell counts resulting in a broadening of immunological repertoire, thus indicating increased thymopoiesis [176-178]. Furthermore, preliminary data from the INSPIRE 2 study indicate that administration of rhIL7 induces expansion of CD4+ cells in the gut mucosa due to increased expression of homing receptors [179] as well as lower expression of PD-1 suggestive of reduced immune activation. Thus, administration of rhIL-7 as supplementary treatment shows great promise. However, as lymphopenic HIV-infected patients present with physiological increased concentration of IL-7 [54, 55], exogenous IL-7 administration might be futile. Fortunately, animal studies [173] and phase I/II clinical trials reveal a significant increase in CD4+ cell count in individuals with low CD4+ cell counts and high IL-7 concentrations (reviewed in [172]). This finding may be due to the fact that circulating levels of IL-7 after rhIL7 administration are much higher than physiological levels. Data from larger randomized clinical trials are warranted to determine the potential effect of adding IL-7 to HAART for immune reconstitution in INR, bearing the result of supplementary administration of IL-2 in mind.

6.4. IL-15. IL-15 is a cytokine that is structurally comparable to IL-2 and regulates proliferation and activation of T cells, and IL-15 has therefore been considered as a potential therapeutic agent in HIV infection. Treatment with IL15 has primarily been investigated in murine and simian models [180, 181] with conflicting results. Combining IL15 and HAART has proven to increase CD4+ cell and
CD8+ cell counts in SIV-infected rhesus macaques (RMs) [182]. However, another study reported no effect of IL-15 administration on CD4+ cell counts but only on CD8+ cell counts and NK cells [181, 183]. Furthermore, administration of IL-15 in acute SIV infection resulted in increased viral load and increased disease progression [183], and similarly adding IL-15 to HAART in SIV-infected RMs resulted in decreased CD4+ cell counts. In conclusion, adding IL-15 to HAART is expected to result in limited benefit for INR.

6.5. Growth Hormone (GH). Studies with supplementary therapy with GH in patients with HIV infection have originally been conducted to examine whether $\mathrm{GH}$ could be used a therapeutic agent for HIV-associated wasting and lipodystrophy (reviewed in $[184,185])$. However, treatment with rhGH supplement to HAART has demonstrated to increase CD4+ cell counts compared to HAART alone in randomized, prospective clinical trials [186-190], and further clinical trials are ongoing (http://www.clinicaltrials.gov/). Furthermore, the supplementary rhGH given subcutaneous in doses from 0.7 to $3 \mathrm{mg} /$ day resulted in an increase in thymic size in alignment with an increase in RTE, TREC number, and naive CD4+ cells [186-190], indicating an increased thymopoiesis. The patients included in these studies had median CD4+ cell counts $<400$ cells/ $\mu \mathrm{L}[187$, 190] and 350 cells/ $\mu \mathrm{L}$ [186], respectively, and may therefore include a group of INR. However, adverse effects such as carpal tunnel syndrome, arthralgia, glucose intolerance, or cancer progression were frequent and result in a limited use of rhGH as a therapeutic agent. A potential strategy to reduce adverse effect is by using $\mathrm{GH}$ releasing factor (GHRF), which seems to cause fewer adverse effects (reviewed in $[191,192])$. However, so far the effects of treatment with GHRF have primarily been addressed to lipodystrophia [192], (http://www.clinicaltrials.gov/), and indeed clinical trials testing the effect of GHRF on immune reconstitution are warranted.

6.6. Keratinocyte Growth Factor (KGF). KGF causes proliferation and differentiation in thymic epithelial cells, and KGF pretreatment in mice and in rhesus macaques after myeloablative irradiation has proven to enhance thymopoiesis and increase thymic output [193-195]. However, a phase I/II randomized placebo-controlled study, originally designed to assess the effect of $40-60 \mu \mathrm{g} / \mathrm{kg}$ KGF per day on graft versus host disease (GVHD) in 100 patients undergoing allogenic hematopoietic stem cell transplantation, showed no effect of KGF on absolute lymphocyte count [196, 197]. Thus, the addition of KGF to enhance immune reconstitution in INR on HAART is theoretically plausible, and results are awaited from a randomized phase II study testing the effect of palifermin (recombinant human KGF) injection at doses from 20 to $60 \mu \mathrm{g} / \mathrm{kg}$ per day in HIV patients on HAART with CD4 count $<250$ cells/ $\mu \mathrm{L}$ (http://www.clinicaltrials.gov/).

6.7. Immune Suppression. The impact of immune activation is described previously. Several strategies have been suggested 
to reduce immune activation. New biological immunomodulators (inhibitors of TNF-alfa, IL-6, IL-1) for autoimmune diseases may prove to be therapeutic possibilities to suppression of immune activation in HIV infection. However, use of such immunomodulators must be done with great care taking into account the increased risks of opportunistic infections. Currently, there is limited experience, but HIV-infected patients with an autoimmune disease have been treated with TNF- $\alpha$ inhibitors with acceptable results for patients with CD $4+$ cell counts $>200$ cells $/ \mu \mathrm{L}$ (reviewed in [198, 199]). A small study described reduced immune activation and increased CD4+ cell count in treatment naïve patients after intravenous immunoglobulin (IVIG) $(0.4 \mathrm{~g} / \mathrm{kg})$ [200]. However, this was not confirmed in another small study reporting no effect of high dosage IVIG (30 gram for five days) in treatment-experienced patients [201, 202], but interestingly IVIG administration resulted in a reduction of HIV reservoirs in CD4+ cell counts after treatment which may be a contributor to the failure of immune recovery in INR. Chronic coinfection with other infectious agents is a potential cause of increased immune activation in HIVinfected patients. Decreased immune activation has been documented after therapeutic clearance of HCV infection with interferon- $\alpha$ and ribavirin [203]. Likewise, a randomized clinical trial including $30 \mathrm{HIV}$-infected patients with CMV coinfection documented a decrease in chronic immune activation after CMV treatment in HIV patients with CD4+ cell counts $<350$ cells $/ \mu \mathrm{L}$ [204]. However, no difference in CD4+ cell count and HIV load was found.

6.8. Microbial Translocation. Microbial translocation has been suggested as a cause of immune activation and CD4+ cell depletion in HIV-infected patients [205-207]. High levels of $16 \mathrm{~S}$ rDNA during therapy have been shown to be associated with reduced increases in the CD4+ cell counts [208], and heightened circulating lipopolysaccharide be associated with plasma enterobacterial DNA [209]. Thus, microbial translocation may be a potential target to decrease immune activation. Probiotics have been tested in randomized clinical trial in HIV-infected patient with CD4+ cell counts above 200 cells/ $\mu \mathrm{L}$; however the results were disappointing [210]. Furthermore, the effects of hyperimmune bovine colostrums on CD4+ cell counts in INR were tested in a randomized clinical trials including 75 patients [163]. No change in immune activation or CD4+ cell counts was found. Thus, strategies to improve immune reconstitution in INR by modulation of microbial translocation are yet to emerge.

6.9. Cox-2 Inhibitor. Finally, another approach suggested to reduce immune activation is cyclooxygenase type 2 (Cox2) inhibitors which have been tested in clinical trials with promising results. Treatment with Cox- 2 inhibitors clearly decreases immune activation in HIV-infected patients [211213], and combination treatment with HAART and Cox2 inhibitor resulted in increased CD4+ cell counts [212, 213]. These studies were conducted in HIV-infected patients with median CD $4+$ cell counts $>400$ cells $/ \mu \mathrm{L}$, and larger clinical trials assessing the effect of Cox-2 inhibitors in INR are needed to uncover a potential for optimizing immune recovery.

\section{Conclusion and Future Directions}

Following the introduction of HAART, the prognosis and life expectancy for HIV-infected patients has changed tremendously. Thus, patients with optimal immune reconstitution and lack of comorbidity have a life expectancy almost comparable to HIV negative individuals. However, rates of morbidity and mortality including both AIDS- and nonAIDS-related events increase substantially with persistent low CD4+ cell counts. Therefore, increased morbidity and mortality persist in patients who do not achieve full immune reconstitution, in particular in INR.

INRs have immunological dysfunctions in both production and destruction of CD4+ cells. A well-functioning bone marrow, a large thymus with adequate function, and a high output of naïve cells are all critical components for production of CD4+ cells and immune reconstitution. It is plausible that dysfunctions in one or more of these parameters contribute to the low CD4+ cell counts in INR. Also, INRs have higher levels of immune activation and apoptotic cells indicating a higher loss of CD4+ cells. With the known significant impact of immune activation on the prognosis in HIV-infected individuals, it is reasonable to conclude that a high level of immune activation is a contributing factor to poor immune reconstitution as well. Furthermore, a dysregulated balance between pro- and anti-inflammatory $\mathrm{T}$ cells in INR may have an influence on immune reconstitution, but definitive documentation is lacking. Finally, it is likely that disruptions in the secondary lymphatic tissue may contribute to lack of immune reconstitution. However, with the present level of knowledge, it is difficult to determine whether these immunological disturbances are reflecting a poor immunological reconstitution rather than causing them. Only well-designed large prospective studies can help clarify this.

So far, a range of supplementary treatment to HAART has been suggested to improve immune reconstitution. The only thoroughly investigated candidate has been IL-2 that unfortunately proved not to be beneficial for clinical outcome. Several candidates seem promising including supplementary treatment with IL-7, GH releasing analogues, and possibly Cox-2 inhibitors. Furthermore, using Maraviroc as an integrated component of HAART does seem to result in higher CD4+ cell counts, but at present, the possibilities of improving the immune reconstitution in INR using supplementary treatment are limited. Some predictive factors can be avoided. Early diagnosis could be improved, reducing the risk for a low CD4 nadir, and coinfection with hepatitis $\mathrm{C}$ can be treated. However, understanding and improving immune reconstitution in HIV-infected patients remains an important field of research.

\section{Conflict of Interests}

The authors have no conflict of Interests. 


\section{References}

[1] N. G. Pakker, D. W. Notermans, R. J. De Boer et al., "Biphasic kinetics of peripheral blood $\mathrm{T}$ cells after triple combination therapy in HIV-1 infection: a composite of redistribution and proliferation," Nature Medicine, vol. 4, no. 2, pp. 208-214, 1998.

[2] B. Autran, G. Carcelaint, T. S. Li et al., "Restoration of the immune system with anti-retroviral therapy," Immunology Letters, vol. 66, no. 1-3, pp. 207-211, 1999.

[3] A. Mocroft, A. Phillips, J. Gatell et al., "Normalisation of CD4 counts in patients with HIV-1 infection and maximum virological suppression who are taking combination antiretroviral therapy: an observational cohort study," Lancet, vol. 370, no. 9585, pp. 407-413, 2007.

[4] C. Piketty, P. Castiel, L. Belec et al., "Discrepant responses to triple combination antiretroviral therapy in advanced HIV disease," AIDS, vol. 12, no. 7, pp. 745-750, 1998.

[5] B. Autran, G. Carcelain, T. S. Li et al., "Positive effects of combined antiretroviral therapy on $\mathrm{CD} 4^{+} \mathrm{T}$ cell homeostasis and function in advanced HIV disease," Science, vol. 277, no. 5322, pp. 112-116, 1997.

[6] M. Marziali, W. De Santis, R. Carello et al., "T-cell homeostasis alteration in HIV-1 infected subjects with low CD4 T-cell count despite undetectable virus load during HAART," AIDS, vol. 20, no. 16, pp. 2033-2041, 2006.

[7] C. Erikstrup, G. Kronborg, N. Lohse, O. S. Rye, J. Gerstoft, and H. Ullum, "T-cell dysfunction in HIV-1-infected patients with impaired recovery of CD4 cells despite suppression of viral replication," Journal of Acquired Immune Deficiency Syndromes, vol. 53, no. 3, pp. 303-310, 2010.

[8] G. Marchetti, L. Gazzola, D. Trabattoni et al., "Skewed Tcell maturation and function in HIV-infected patients failing $\mathrm{CD}^{+}{ }^{+}$recovery upon long-term virologically suppressive HAART," AIDS, vol. 24, no. 10, pp. 1455-1460, 2010.

[9] T. Li, N. Wu, Y. Dai et al., "Reduced thymic output is a major mechanism of immune reconstitution failure in HIV-infected patients after long-term antiretroviral therapy," Clinical Infectious Diseases, vol. 53, no. 9, pp. 944-951, 2011.

[10] C. Lewden, G. Chêne, P. Morlat et al., "HIV-infected adults with a CD4 cell count greater than 500 cells $/ \mathrm{mm} 3$ on long-term combination antiretroviral therapy reach same mortality rates as the general population," Journal of Acquired Immune Deficiency Syndromes, vol. 46, no. 1, pp. 72-77, 2007.

[11] "Life expectancy of individuals on combination antiretroviral therapy in high-income countries: a collaborative analysis of 14 cohort studies," Lancet, vol. 372, no. 9635, pp. 293-299, 2008.

[12] C. Piketty, L. Weiss, F. Thomas, A. S. Mohamed, L. Belec, and M. D. Kazatchkine, "Long-term clinical outcome of human immunodeficiency virus-infected patients with discordant immunologic and virologic responses to a protease inhibitorcontaining regimen," Journal of Infectious Diseases, vol. 183, no. 9, pp. 1328-1335, 2001.

[13] F. N. Engsig, J. Gerstoft, G. Kronborg et al., "Long-term mortality in HIV patients virally suppressed for more than three years with incomplete CD4 recovery: a cohort study," BMC Infectious Diseases, p. 318, 2010.

[14] R. D. Moore and J. C. Keruly, "CD4+ cell count 6 years after commencement of highly active antiretroviral therapy in persons with sustained virologic suppression," Clinical Infectious Diseases, vol. 44, no. 3, pp. 441-446, 2007.
[15] R. D’Amico, Y. Yang, D. Mildvan et al., "Lower CD4 ${ }^{+}$T lymphocyte nadirs may indicate limited immune reconstitution in HIV-1 infected individuals on potent antiretroviral therapy: analysis of immunophenotypic marker results of AACTG 5067," Journal of Clinical Immunology, vol. 25, no. 2, pp. 106-115, 2005.

[16] G. R. Kaufmann, H. Furrer, B. Ledergerber et al., "Characteristics, determinants, and clinical relevance of CD4 T cell recovery to $<500$ cells $/ \mu \mathrm{L}$ in HIV type 1 -infected individuals receiving potent antiretroviral therapy," Clinical Infectious Diseases, vol. 41, no. 3, pp. 361-372, 2005.

[17] G. Greub, B. Ledergerber, M. Battegay et al., "Clinical progression, survival, and immune recovery during antiretroviral therapy in patients with HIV-1 and hepatitis C virus coinfection: the swiss HIV cohort study," Lancet, vol. 356, no. 9244, pp. 1800-1805, 2000.

[18] L. Kolte, C. Strandberg, A. M. Dreves et al., "Thymic involvement in immune recovery during antiretroviral treatment of HIV infection in adults; comparison of CT and sonographic findings," Scandinavian Journal of Infectious Diseases, vol. 34, no. 9, pp. 668-672, 2002.

[19] L. Kolte, A. M. Dreves, A. K. Ersbøll et al., "Association between larger thymic size and higher thymic output in human immunodeficiency virus-infected patients receiving highly active antiretroviral therapy," Journal of Infectious Diseases, vol. 185, no. 11, pp. 1578-1585, 2002.

[20] A. Vigano, S. Vella, N. Principi et al., "Thymus volume correlates with the progression of vertical HIV infection," AIDS, vol. 13, no. 5, pp. F29-F34, 1999.

[21] D. C. Douek, R. A. Vescio, M. R. Betts et al., "Assessment of thymic output in adults after haematopoietic stem-cell transplantation and prediction of T-cell reconstitution," Lancet, vol. 355, no. 9218, pp. 1875-1881, 2000.

[22] B. F. Haynes, M. L. Markert, G. D. Sempowski, D. D. Patel, and L. P. Hale, "The role of the thymus in immune reconstitution in aging, bone marrow transplantation, and HIV-1 infection," Annual Review of Immunology, vol. 18, pp. 529-560, 2000.

[23] J. M. McCune, R. Loftus, D. K. Schmidt et al., "High prevalence of thymic tissue in adults with human immunodeficiency virus-1 infection," Journal of Clinical Investigation, vol. 101, no. 11, pp. 2301-2308, 1998.

[24] K. Y. Smith, H. Valdez, A. Landay et al., "Thymic size and lymphocyte restoration in patients with human immunodeficiency virus infection after 48 weeks of zidovudine, lamivudine, and ritonavir therapy," Journal of Infectious Diseases, vol. 181, no. 1, pp. 141-147, 2000.

[25] B. D. Jamieson, D. C. Douek, S. Killian et al., "Generation of functional thymocytes in the human adult," Immunity, vol. 10, no. 5, pp. 569-575, 1999.

[26] G. Khoury, R. Rajasuriar, P. U. Cameron, and S. R. Lewin, "The role of naive T-cells in HIV-1 pathogenesis: an emerging key player," Clinical Immunology, vol. 141, no. 3, pp. 253-267, 2011.

[27] S. Kimmig, G. K. Przybylski, C. A. Schmidt et al., "Two subsets of naive $\mathrm{T}$ helper cells with distinct $\mathrm{T}$ cell receptor excision circle content in human adult peripheral blood," Journal of Experimental Medicine, vol. 195, no. 6, pp. 789794, 2002.

[28] S. Junge, B. Kloeckener-Gruissem, R. Zufferey et al., "Correlation between recent thymic emigrants and $\mathrm{CD} 31+$ (PECAM-1) $\mathrm{CD}^{+} \mathrm{T}$ cells in normal individuals during aging and in lymphopenic children," European Journal of Immunology, vol. 37, no. 11, pp. 3270-3280, 2007. 
[29] M. D. Hazenberg, S. A. Otto, J. W. T. C. Stuart et al., "Increased cell division but not thymic dysfunction rapidly affects the T-cell receptor excision circle content of the naive T cell population in HIV-1 infection," Nature Medicine, vol. 6, no. 9, pp. 1036-1042, 2000.

[30] D. C. Douek, R. D. McFarland, P. H. Keiser et al., "Changes in thymic function with age and during the treatment of HIV infection," Nature, vol. 396, no. 6712, pp. 690-695, 1998.

[31] L. Zhang, S. R. Lewin, M. Markowitz et al., "Measuring recent thymic emigrants in blood of normal and HIV-1-infected individuals before and after effective therapy," Journal of Experimental Medicine, vol. 190, no. 5, pp. 725-732, 1999.

[32] N. Vrisekoop, R. Van Gent, A. B. De Boer et al., "Restoration of the CD4 $\mathrm{T}$ cell compartment after long-term highly active antiretroviral therapy without phenotypical signs of accelerated immunological aging," Journal of Immunology, vol. 181, no. 2, pp. 1573-1581, 2008.

[33] S. Tanaskovic, S. Fernandez, M. A. French et al., "Thymic tissue is not evident on high-resolution computed tomography and $[18 \mathrm{~F}]$ Fluoro-deoxy-glucose positron emission tomography scans of aviraemic HIV patients with poor recovery of $\mathrm{CD}^{+} \mathrm{T}$ cells," AIDS, vol. 25, no. 9, pp. 12351237, 2011.

[34] A. Isgrò, W. Leti, W. De Santis et al., "Altered clonogenic capability and stromal cell function characterize bone marrow of HIV-infected subjects with low $\mathrm{CD} 4^{+} \mathrm{T}$ cell counts despite viral suppression during HAART," Clinical Infectious Diseases, vol. 46, no. 12, pp. 1902-1910, 2008.

[35] P. Delobel, M. T. Nugeyre, M. Cazabat et al., "Naïve T-cell depletion related to infection by $\mathrm{X} 4$ human immunodeficiency virus type 1 in poor immunological responders to highly active antiretroviral therapy," Journal of Virology, vol. 80, no. 20, pp. 10229-10236, 2006.

[36] G. Marchetti, A. Gori, A. Casabianca et al., "Comparative analysis of T-cell turnover and homeostatic parameters in HIV-infected patients with discordant immune-virological responses to HAART," AIDS, vol. 20, no. 13, pp. 1727-1736, 2006.

[37] L. Kolte, L. P. Ryder, E. Albrecht-Beste, F. K. Jensen, and S. D. Nielsen, "HIV-infected patients with a large thymus maintain higher CD4 counts in a 5-year follow-up study of patients treated with highly active antiretroviral therapy," Scandinavian Journal of Immunology, vol. 70, no. 6, pp. 608613, 2009.

[38] S. Molina-Pinelo, J. Vivancos, B. De Felipe et al., "Thymic volume predicts CD4 T-cell decline in HIV-infected adults under prolonged treatment interruption," Journal of Acquired Immune Deficiency Syndromes, vol. 42, no. 2, pp. 203-206, 2006.

[39] F. García, M. Plana, G. Mestre et al., "Immunological and virological factors at baseline may predict response to structured therapy interruption in early stage chronic HIV1 infection," AIDS, vol. 16, no. 13, pp. 1761-1765, 2002.

[40] R. Van Gent, A. W.L. Schadenberg, S. A. Otto et al., "Longterm restoration of the human T-cell compartment after thymectomy during infancy: a role for thymic regeneration?" Blood, vol. 118, no. 3, pp. 627-634, 2011.

[41] G. Hütter and S. Ganepola, "Eradication of HIV by transplantation of CCR5-deficient hematopoietic stem cells," The Scientific World Journal, vol. 11, pp. 1068-1076, 2011.

[42] A. Marandin, A. Katz, E. Oksenhendler et al., "Loss of primitive hematopoietic progenitors in patients with human immunodeficiency virus infection," Blood, vol. 88, no. 12, pp. 4568-4578, 1996.
[43] A. Moses, J. Nelson, and G. C. Bagby, "The influence of human immunodeficiency virus-1 on hematopoiesis," Blood, vol. 91, no. 5, pp. 1479-1495, 1998.

[44] M. Jenkins, M. B. Hanley, M. B. Moreno, E. Wieder, and J. M. McCune, "Human immunodeficiency virus-1 infection interrupts thymopoiesis and multilineage hematopoiesis in vivo," Blood, vol. 91, no. 8, pp. 2672-2678, 1998.

[45] A. Alexaki and B. Wigdahl, "HIV-1 infection of bone marrow hematopoietic progenitor cells and their role in trafficking and viral dissemination," PLoS Pathogens, vol. 4, no. 12, Article ID e1000215, 2008.

[46] C. C. Carter, A. Onafuwa-Nuga, L. A. McNamara et al., "HIV1 infects multipotent progenitor cells causing cell death and establishing latent cellular reservoirs," Nature Medicine, vol. 16, no. 4, pp. 446-451, 2010.

[47] S. Moir, J. Ho, A. Malaspina et al., "Evidence for HIVassociated B cell exhaustion in a dysfunctional memory B cell compartment in HIV-infected viremic individuals," Journal of Experimental Medicine, vol. 205, no. 8, pp. 1797-1805, 2008.

[48] J. W. Goodman and G. S. Hodgson, "Evidence for stem cells in the peripheral blood of mice," Blood, vol. 19, pp. 702-714, 1962.

[49] D. Sauce, M. Larsen, S. Fastenackels et al., "HIV disease progression despite suppression of viral replication is associated with exhaustion of lymphopoiesis," Blood, vol. 117, no. 19, pp. 5142-5151, 2011.

[50] S. D. Nielsen, P. Afzelius, S. Dam-Larsen et al., "Effect of granulocyte colony-stimulating factor (G-CSF) in human immunodeficiency virus-infected patients: increase in numbers of naive CD4 cells and CD34 cells makes G-CSF a candidate for use in gene therapy or to support antiretroviral therapy," Journal of Infectious Diseases, vol. 177, no. 6, pp. 1733-1736, 1998.

[51] D. R. Clark, N. M. Ampel, C. A. Hallett, V. R. K. Yedavalli, N. Ahmad, and D. DeLuca, "Peripheral blood from human immunodeficiency virus type 1-infected patients displays diminished T cell generation capacity," Journal of Infectious Diseases, vol. 176, no. 3, pp. 649-654, 1997.

[52] L. S. Park, D. J. Friend, A. E. Schmierer, S. K. Dower, and A. E. Namen, "Murine interleukin 7 (IL-7) receptor. Characterization on an IL-7-dependent cell line," Journal of Experimental Medicine, vol. 171, no. 4, pp. 1073-1089, 1990.

[53] K. S. Schluns, W. C. Kieper, S. C. Jameson, and L. Lefrançois, "Interleukin-7 mediates the homeostasis of naïve and memory CD8 T cells in vivo," Nature Immunology, vol. 1, no. 5, pp. 426-432, 2000.

[54] A. Llano, J. Barretina, A. Gutiérrez et al., "Interleukin-7 in plasma correlates with CD4 T-cell depletion and may be associated with emergence of syncytium-inducing variants in human immunodeficiency virus type 1-positive individuals," Journal of Virology, vol. 75, no. 21, pp. 10319-10325, 2001.

[55] B. Rethi, C. Fluur, A. Atlas et al., "Loss of IL-7R $\alpha$ is associated with CD4 T-cell depletion, high interleukin-7 levels and CD28 down-regulation in HIV infected patients," AIDS, vol. 19, no. 18, pp. 2077-2086, 2005.

[56] G. M. Bellistri, A. Casabianca, E. Merlini et al., "Increased bone marrow interleukin-7 (IL-7)/IL-7R levels but reduced IL-7 responsiveness in HIV-positive patients lacking $\mathrm{CD}^{+}$ gain on antiviral therapy," PLOS ONE, vol. 5, no. 12, article e15663, 2010.

[57] A. Leone, L. J. Picker, and D. L. Sodora, "IL-2, IL-7 and IL15 as immuno-modulators during SIV/HIV vaccination and 
treatment," Current HIV Research, vol. 7, no. 1, pp. 83-90, 2009.

[58] A. Ahmad, R. Ahmad, A. Iannello, E. Toma, R. Morisset, and S. T. A. K. Sindhu, "IL-15 and HIV infection: lessons for immunotherapy and vaccination," Current HIV Research, vol. 3, no. 3, pp. 261-270, 2005.

[59] D. Sirskyj, J. Thèze, A. Kumar, and M. Kryworuchko, "Disruption of the $\gamma c$ cytokine network in T cells during HIV infection," Cytokine, vol. 43, no. 1, pp. 1-14, 2008.

[60] M. D. Hazenberg, S. A. Otto, B. H. B. van Benthem et al., "Persistent immune activation in HIV-1 infection is associated with progression to AIDS," AIDS, vol. 17, no. 13, pp. 1881-1888, 2003.

[61] Z. Liu, W. G. Cumberland, L. E. Hultin, A. H. Kaplan, R. Detels, and J. V. Giorgi, "CD8 ${ }^{+}$T-lymphocyte activation in HIV-1 disease reflects an aspect of pathogenesis distinct from viral burden and immunodeficiency," Journal of Acquired Immune Deficiency Syndromes and Human Retrovirology, vol. 18, no. 4, pp. 332-340, 1998.

[62] Z. Liu, W. G. Cumberland, L. E. Hultin, H. E. Prince, R. Detels, and J. V. Giorgi, "Elevated CD38 antigen expression on $\mathrm{CD}^{+} \mathrm{T}$ cells Is a stronger marker for the risk of chronic HIV disease progression to AIDS and death in the multicenter AIDS Cohort study than $\mathrm{CD}^{+}$cell count, soluble immune activation markers, or combinations of HLA-DR and CD38 expression," Journal of Acquired Immune Deficiency Syndromes and Human Retrovirology, vol. 16, no. 2, pp. 83-92, 1997.

[63] Z. Liu, L. E. Hultin, W. G. Cumberland et al., "Elevated relative fluorescence intensity of CD38 antigen expression on $\mathrm{CD}^{+} \mathrm{T}$ cells is a marker of poor prognosis in HIV infection: results of 6 years of follow-up," Communications in Clinical Cytometry, vol. 26, no. 1, pp. 1-7, 1996.

[64] J. V. Giorgi, Z. Liu, L. E. Hultin, W. G. Cumberland, K. Hennessey, and R. Detels, "Elevated levels of CD $38^{+} \mathrm{CD} 8^{+}$ $T$ cells in HIV infection add to the prognostic value of low $\mathrm{CD}^{+} \mathrm{T}$ cell levels: results of 6 years of follow-up," Journal of Acquired Immune Deficiency Syndromes, vol. 6, no. 8, pp. 904-912, 1993.

[65] L. Weiss, N. Haeffner-Cavaillon, M. Laude, J. Gilquin, and M. D. Kazatchkine, "HIV infection is associated with the spontaneous production of interleukin-1 (IL-1) in vivo and with an abnormal release of IL- $1 \alpha$ in vitro," AIDS, vol. 3, no. 11, pp. 695-699, 1989.

[66] J. M. Molina, D. T. Scadden, R. Byrn, C. A. Dinarello, and J. E. Groopman, "Production of tumor necrosis factor $\alpha$ and interleukin $1 \beta$ by monocytic cells infected with human immunodeficiency virus," Journal of Clinical Investigation, vol. 84, no. 3, pp. 733-737, 1989.

[67] D. Emilie, M. Peuchmaur, M. C. Maillot et al., "Production of interleukins in human immunodeficiency virus-1-replicating lymph nodes," Journal of Clinical Investigation, vol. 86, no. 1, pp. 148-159, 1990.

[68] D. L. Birx, R. R. Redfield, K. Tencer, A. Fowler, D. S. Burke, and G. Tosato, "Induction of interleukin-6 during human immunodeficiency virus infection," Blood, vol. 76, no. 11, pp. 2303-2310, 1990.

[69] J. V. Giorgi, L. E. Hultin, J. A. McKeating et al., "Shorter survival in advanced human immunodeficiency virus type 1 infection is more closely associated with $\mathrm{T}$ lymphocyte activation than with plasma virus burden or virus chemokine coreceptor usage," Journal of Infectious Diseases, vol. 179, no. 4, pp. 859-870, 1999.
[70] A. E. Sousa, J. Carneiro, M. Meier-Schellersheim, Z. Grossman, and R. M. M. Victorino, "CD4 T cell depletion is linked directly to immune activation in the pathogenesis of HIV-1 and HIV-2 but only indirectly to the viral load," Journal of Immunology, vol. 169, no. 6, pp. 3400-3406, 2002.

[71] Z. Grossman, M. Meier-Schellersheim, A. E. Sousa, R. M. M. Victorino, and W. E. Paul, "CD4 ${ }^{+}$T-cell depletion in HIV infection: are we closer to understanding the cause?" Nature Medicine, vol. 8, no. 4, pp. 319-323, 2002.

[72] R. E. Owen, J. W. Heitman, D. F. Hirschkorn et al., "HIV+ elite controllers have low HIV-specific T-cell activation yet maintain strong, polyfunctional T-cell responses," AIDS, vol. 24, no. 8, pp. 1095-1105, 2010.

[73] S. R. Broussard, S. I. Staprans, R. White, E. M. Whitehead, M. B. Feinberg, and J. S. Allan, "Simian immunodeficiency virus replicates to high levels in naturally infected African green monkeys without inducing immunologic or neurologic disease," Journal of Virology, vol. 75, no. 5, pp. 2262-2275, 2001.

[74] A. Kaur, R. M. Grant, R. E. Means, H. Mcclure, M. Feinberg, and R. P. Johnson, "Diverse host responses and outcomes following simian immunodeficiency virus SIVmac239 infection in sooty mangabeys and rhesus macaques," Journal of Virology, vol. 72, no. 12, pp. 9597-9611, 1998.

[75] E. L. Pesanti, "Effects of bacterial pneumonitis on development of pneumocystosis in rats," American Review of Respiratory Disease, vol. 125, no. 6, pp. 723-726, 1982.

[76] M. D. Hazenberg, D. Hamann, H. Schuitemaker, and F. Miedema, "T cell depletion in HIV-1 infection: how $\mathrm{CD}^{+}$ T cells go out of stock," Nature Immunology, vol. 1, no. 4, pp. 285-289, 2000.

[77] J. M. Benito, M. López, J. C. Martín et al., "Differences in cellular activation and apoptosis in HIV-infected patients receiving protease inhibitors or nonnucleoside reverse transcriptase inhibitors," AIDS Research and Human Retroviruses, vol. 18, no. 18, pp. 1379-1388, 2002.

[78] P. W. Hunt, J. Brenchley, E. Sinclair et al., "Relationship between $\mathrm{T}$ cell activation and $\mathrm{CD}^{+}{ }^{+} \mathrm{T}$ cell count in HIVseropositive individuals with undetectable plasma HIV RNA levels in the absence of therapy," Journal of Infectious Diseases, vol. 197, no. 1, pp. 126-133, 2008.

[79] M. Massanella, E. Negredo, N. Pérez-Álvarez et al., "CD4 Tcell hyperactivation and susceptibility to cell death determine poor CD4 T-cell recovery during suppressive HAART," AIDS, vol. 24, no. 7, pp. 959-968, 2010.

[80] D. Nakanjako, I. Ssewanyana, H. Mayanja-Kizza et al., "High T-cell immune activation and immune exhaustion among individuals with suboptimal CD4 recovery after 4 years of antiretroviral therapy in an African cohort," BMC Infectious Diseases, vol. 11, article 43, 2011.

[81] J. M. Benito, M. López, S. Lozano et al., " $C D 4^{+}$T cell recovery beyond the first year of complete suppression of viral replication during highly active antiretroviral therapy is not influenced by $\mathrm{CD}^{+} \mathrm{T}$ cell activation," Journal of Infectious Diseases, vol. 192, no. 12, pp. 2142-2146, 2005.

[82] R. L. Gascon, A. B. Narváez, R. Zhang et al., "Increased HLADR expression on peripheral blood monocytes in subsets of subjects with primary HIV infection is associated with elevated CD4 T-cell apoptosis and CD4 T-cell depletion," Journal of Acquired Immune Deficiency Syndromes, vol. 30, no. 2, pp. 146-153, 2002.

[83] M. Mavigenr, P. Delobel, M. Cazabat et al., "HIV-1 residual viremia correlates with persistent T-cell activation in poor 
immunological responders to combination antiretroviral therapy," PLoS ONE, vol. 4, no. 10, Article ID e7658, 2009.

[84] P. Delobel, S. Flament, M. Hamdane et al., "Abnormal Tau phosphorylation of the Alzheimer-type also occurs during mitosis," Journal of Neurochemistry, vol. 83, no. 2, pp. 412420, 2002.

[85] R. Hazra and C. Mackall, "Thymic function in HIV infection," Current HIV/AIDS Reports, vol. 2, no. 1, pp. 24-28, 2005.

[86] R. B. Effros and G. Pawelec, "Replicative senescence of T cells: does the Hayflick Limit lead to immune exhaustion?" Immunology Today, vol. 18, no. 9, pp. 450-454, 1997.

[87] K. C. Wolthers, G. B. A. Wisman, S. A. Otto et al., "T cell telomere length in HIV-1 infection: no evidence for increased CD4 ${ }^{+}$T cell turnover," Science, vol. 274, no. 5292, pp. $1543-$ 1547, 1996.

[88] M. Dagarag, H. Ng, R. Lubong, R. B. Effros, and O. O. Yang, "Differential impairment of lytic and cytokine functions in senescent human immunodeficiency virus type 1-specific cytotoxic T lymphocytes," Journal of Virology, vol. 77, no. 5, pp. 3077-3083, 2003.

[89] O. Franzese, R. Adamo, M. Pollicita et al., "Telomerase activity, hTERT expression, and phosphorylation are downregulated in $\mathrm{CD}^{+} \mathrm{T}$ lymphocytes infected with human immunodeficiency virus type 1 (HIV-1)," Journal of Medical Virology, vol. 79, no. 5, pp. 639-646, 2007.

[90] L. Meyaard, S. A. Otto, R. R. Jonker, M. J. Mijnster, R. P. M. Keet, and F. Miedema, "Programmed death of T cells in HIV1 infection,” Science, vol. 257, no. 5067, pp. 217-219, 1992.

[91] L. Meyaard, S. A. Otto, I. P. M. Keet, M. T. L. Roos, and F. Miedema, "Programmed death of T cells in human immunodeficiency virus infection. No correlation with progression to disease," Journal of Clinical Investigation, vol. 93, no. 3, pp. 982-988, 1994.

[92] F. Bottarel, S. Bonissoni, M. B. Lucia et al., "Decreased function of Fas in patients displaying delayed progression of HIV-induced immune deficiency," Hematology Journal, vol. 2, no. 4, pp. 220-227, 2001.

[93] M. L. Gougeon, H. Lecoeur, A. Dulioust et al., "Programmed cell death in peripheral lymphocytes from HIV-infected persons: increased susceptibility to apoptosis of CD4 and CD8 T cells correlates with lymphocyte activation and with disease progression," Journal of Immunology, vol. 156, no. 9, pp. 3509-3520, 1996.

[94] S. Piconi, D. Trabattoni, A. Gori et al., "Immune activation, apoptosis, and treg activity are associated with persistently reduced $\mathrm{CD}^{+}$T-cell counts during antiretroviral therapy," AIDS, vol. 24, no. 13, pp. 1991-2000, 2010.

[95] M. E. Keir, M. J. Butte, G. J. Freeman, and A. H. Sharpe, "PD1 and its ligands in tolerance and immunity," Annual Review of Immunology, vol. 26, pp. 677-704, 2008.

[96] D. L. Barber, E. J. Wherry, D. Masopust et al., "Restoring function in exhausted CD8 $\mathrm{T}$ cells during chronic viral infection," Nature, vol. 439, no. 7077, pp. 682-687, 2006.

[97] K. Grabmeier-Pfistershammer, P. Steinberger, A. Rieger, J. Leitner, and N. Kohrgruber, "Identification of PD-1 as a unique marker for failing immune reconstitution in HIV-1infected patients on treatment," Journal of Acquired Immune Deficiency Syndromes, vol. 56, no. 2, pp. 118-124, 2011.

[98] V. Appay, S. Fastenackels, C. Katlama et al., "Old age and anticytomegalovirus immunity are associated with altered T-cell reconstitution in HIV-1-infected patients," AIDS, vol. 25, no. 15, pp. 1813-1822, 2011.
[99] C. Steininger, E. Puchhammer-Stöckl, and T. PopowKraupp, "Cytomegalovirus disease in the era of highly active antiretroviral therapy (HAART)," Journal of Clinical Virology, vol. 37, no. 1, pp. 1-9, 2006.

[100] S. Read, S. Mauze, C. Asseman, A. Bean, R. Coffman, and F. Powrie, "CD38 ${ }^{+} \mathrm{CD} 45 \mathrm{RB}$ (low) $\mathrm{CD} 4{ }^{+} \mathrm{T}$ cells: a population of T cells with immune regulatory activities in vitro," European Journal of Immunology, vol. 28, no. 11, pp. 3435-3447, 1998.

[101] C. Baecher-Allan, J. A. Brown, G. J. Freeman, and D. A. Hafler, "CD4 ${ }^{+} \mathrm{CD} 25$ high regulatory cells in human peripheral blood," Journal of Immunology, vol. 167, no. 3, pp. 1245-1253, 2001.

[102] A. Yoshizawa, A. Ito, Y. Li et al., "The roles of CD $25^{+} \mathrm{CD} 4^{+}$ regulatory $\mathrm{T}$ cells in operational tolerance after living donor liver transplantation," Transplantation Proceedings, vol. 37, no. 1, pp. 37-39, 2005.

[103] S. Sakaguchi, "Naturally arising Foxp3-expressing CD $25^{+}$ $\mathrm{CD}^{+}$regulatory $\mathrm{T}$ cells in immunological tolerance to self and non-self," Nature Immunology, vol. 6, no. 4, pp. 345-352, 2005.

[104] K. Oswald-Richter, S. M. Grill, N. Shariat et al., "HIV infection of naturally occurring and genetically reprogrammed human regulatory T-cells," PLoS Biology, vol. 2, no. 7, 2004.

[105] S. Tsunemi, T. Iwasaki, T. Imado et al., "Relationship of $\mathrm{CD} 4^{+} \mathrm{CD} 25^{+}$regulatory $\mathrm{T}$ cells to immune status in HIVinfected patients," AIDS, vol. 19, no. 9, pp. 879-886, 2005.

[106] J. C. Gaardbo, S. D. Nielsen, S. J. Vedel et al., "Regulatory T cells in human immunodeficiency virus-infected patients are elevated and independent of immunological and virological status, as well as initiation of highly active anti-retroviral therapy," Clinical and Experimental Immunology, vol. 154, no. 1, pp. 80-86, 2008.

[107] L. Kolte, J. C. Gaardbo, K. Skogstrand, L. P. Ryder, A. K. Ersbøll, and S. D. Nielsen, "Increased levels of regulatory $\mathrm{T}$ cells (Tregs) in human immunodeficiency virus-infected patients after 5 years of highly active anti-retroviral therapy may be due to increased thymic production of naive Tregs," Clinical and Experimental Immunology, vol. 155, no. 1, pp. 44-52, 2009.

[108] A. Lim, D. Tan, P. Price et al., "Proportions of circulating $\mathrm{T}$ cells with a regulatory cell phenotype increase with HIV-associated immune activation and remain high on antiretroviral therapy," AIDS, vol. 21, no. 12, pp. 1525-1534, 2007.

[109] S. S. Bernardes, I. K. Borges, J. E. Lima et al., "Involvement of regulatory T cells in HIV immunopathogenesis," Current HIV Research, vol. 8, no. 4, pp. 340-346, 2010.

[110] E. Bettelli, Y. Carrier, W. Gao et al., "Reciprocal developmental pathways for the generation of pathogenic effector TH17 and regulatory T cells," Nature, vol. 441, no. 7090, pp. 235238, 2006.

[111] D. Favre, S. Lederer, B. Kanwar et al., "Critical loss of the balance between Th17 and T regulatory cell populations in pathogenic SIV infection," PLoS Pathogens, vol. 5, no. 2, Article ID e1000295, 2009.

[112] D. Favre, J. Mold, P. W. Hunt et al., “Tryptophan catabolism by indoleamine 2, 3-dioxygenase 1 alters the balance of TH17 to regulatory T cells in HIV disease," Science Translational Medicine, vol. 2, no. 32, pp. 32-36, 2010.

[113] P. W. Hunt, "Th17, gut, and HIV: therapeutic implications," Current Opinion in HIV and AIDS, vol. 5, no. 2, pp. 189-193, 2010.

[114] L. Brandt, T. Benfield, H. Mens et al., "Low level of regulatory $\mathrm{T}$ cells and maintenance of balance between regulatory $\mathrm{T}$ cells 
and TH17 cells in HIV-1-infected elite controllers," Journal of Acquired Immune Deficiency Syndromes, vol. 57, no. 2, pp. 101-108, 2011.

[115] D. J. Hartigan-O’Connor, L. A. Hirao, J. M. McCune, and S. Dandekar, "Th17 cells and regulatory T cells in elite control over HIV and SIV," Current Opinion in HIV and AIDS, vol. 6, no. 3, pp. 221-227, 2011.

[116] J. Gaardbo et al., "Regulatory T cells (Tregs) are extremely prevalent in HIV infected individuals with immunological non-response, oral presentation PS12/2," European AIDS Clinical Society. In press.

[117] J. J. Mattapallil, D. C. Douek, B. Hill, Y. Nishimura, M. Martin, and M. Roederer, "Massive infection and loss of memory $\mathrm{CD}^{+} \mathrm{T}$ cells in multiple tissues during acute SIV infection," Nature, vol. 434, no. 7037, pp. 1093-1097, 2005.

[118] M. Guadalupe, E. Reay, S. Sankaran et al., "Severe CD4 ${ }^{+}$Tcell depletion in gut lymphoid tissue during primary human immunodeficiency virus type 1 infection and substantial delay in restoration following highly active antiretroviral therapy," Journal of Virology, vol. 77, no. 21, pp. 11708-11717, 2003.

[119] T. W. Schacker, P. L. Nguyen, G. J. Beilman et al., "Collagen deposition in HIV-1 infected lymphatic tissues and T cell homeostasis," Journal of Clinical Investigation, vol. 110, no. 8, pp. 1133-1139, 2002.

[120] T. W. Schacker, C. Reilly, G. J. Beilman et al., "Amount of lymphatic tissue fibrosis in HIV infection predicts magnitude of HAART-associated change in peripheral CD4 cell count," AIDS, vol. 19, no. 18, pp. 2169-2171, 2005.

[121] T. H. Finkel, G. Tudor-Williams, N. K. Banda et al., "Apoptosis occurs predominantly in bystander cells and not in productively infected cells of HIV- and SIV-infected lymph nodes," Nature Medicine, vol. 1, no. 2, pp. 129-134, 1995.

[122] D. Finzi, M. Hermankova, T. Pierson et al., "Identification of a reservoir for HIV-1 in patients on highly active antiretroviral therapy," Science, vol. 278, no. 5341, pp. 12951300, 1997.

[123] W. Cavert, D. W. Notermans, K. Staskus et al., "Kinetics of response in lymphoid tissues to antiretroviral therapy of HIV-1 infection," Science, vol. 276, no. 5314, pp. 960-964, 1997.

[124] T. W. Chun, D. C. Nickle, J. S. Justement et al., "Persistence of HIV in gut-associated lymphoid tissue despite long-term antiretroviral therapy," Journal of Infectious Diseases, vol. 197, no. 5, pp. 714-720, 2008.

[125] N. Chomont, M. El-Far, P. Ancuta et al., "HIV reservoir size and persistence are driven by T cell survival and homeostatic proliferation," Nature Medicine, vol. 15, no. 8, pp. 893-900, 2009.

[126] L. Wang, C. W. Robb, and M. W. Cloyd, "HIV induces homing of resting T lymphocytes to lymph nodes," Virology, vol. 228, no. 2, pp. 141-152, 1997.

[127] L. Wang, J. J. Y. Chen, B. B. Gelman, R. Konig, and M. W. Cloyd, "A novel mechanism of CD4 lymphocyte depletion involves effects of HIV on resting lymphocytes: induction of lymph node homing and apoptosis upon secondary signaling through homing receptors," Journal of Immunology, vol. 162, no. 1, pp. 268-276, 1999.

[128] M. W. Cloyd, J. J. Y. Chen, P. Adeqboyega, and L. Wang, "How does HIV cause depletion of CD4 lymphocytes? A mechanism involving virus signaling through its cellular receptors," Current Molecular Medicine, vol. 1, no. 5, pp. 545$550,2001$.
[129] H. J. Epple, C. Loddenkemper, D. Kunkel et al., "Mucosal but not peripheral FOXP3+ regulatory $\mathrm{T}$ cells are highly increased in untreated HIV infection and normalize after suppressive HAART," Blood, vol. 108, no. 9, pp. 3072-3078, 2006.

[130] K. Bhaskaran, O. Hamouda, M. Sannes et al., "Changes in the risk of death after HIV seroconversion compared with mortality in the general population," JAMA - Journal of the American Medical Association, vol. 300, no. 1, pp. 51-59, 2008.

[131] F. Fedele, N. Bruno, and M. Mancone, "Cardiovascular risk factors and HIV disease," AIDS Reviews, vol. 13, no. 2, pp. 119-129, 2011.

[132] S. K. Grinspoon, "Metabolic syndrome and cardiovascular disease in patients with human immunodeficiency virus," The American Journal of Medicine, vol. 118, supplement 2, pp. 23S-28S, 2005.

[133] S. G. Deeks, "Antiretroviral treatment of HIV infected adults," British Medical Journal, vol. 332, no. 7556, pp. 14891493, 2006.

[134] N. R. Reynolds, "Cigarette smoking and HIV: more evidence for action," AIDS Education and Prevention, vol. 21, no. 3, pp. 106-121, 2009.

[135] H. Van Tieu and B. A. Koblin, "HIV, alcohol, and noninjection drug use," Current Opinion in HIV and AIDS, vol. 4, no. 4, pp. 314-318, 2009.

[136] A. A. Adimora and J. D. Auerbach, "Structural interventions for HIV prevention in the United States," Journal of Acquired Immune Deficiency Syndromes, vol. 55, no. 2, supplement, pp. S132-S135, 2010.

[137] R. Greener and S. Sarkar, "Risk and vulnerability: do socioeconomic factors influence the risk of acquiring HIV in Asia?" AIDS, vol. 24, no. 3, supplement, pp. S3-S11, 2010.

[138] J. D. Lundgren, A. Babiker, W. El-Sadr et al., "Inferior clinical outcome of the $\mathrm{CD} 4^{+}$cell count-guided antiretroviral treatment interruption strategy in the SMART study: role of $\mathrm{CD}^{+}$cell counts and HIV RNA levels during follow-up," Journal of Infectious Diseases, vol. 197, no. 8, pp. 1145-1155, 2008.

[139] F. Gutiérrez, S. Padilla, M. Masiá et al., "Patients' characteristics and clinical implications of suboptimal CD4 T-cell gains after 1 year of successful antiretroviral therapy," Current HIV Research, vol. 6, no. 2, pp. 100-107, 2008.

[140] A. N. Phillips, B. Gazzard, R. Gilson et al., "Rate of AIDS diseases or death in HIV-infected antiretroviral therapynaive individuals with high CD4 cell count," AIDS, vol. 21, no. 13, pp. 1717-1721, 2007.

[141] N. Obel, L. H. Omland, G. Kronborg et al., "Impact of Non-HIV and HIV risk factors on survival in HIV-Infected patients on haart: a population-based nationwide cohort study," PLoS ONE, vol. 6, no. 7, article e22698, 2011.

[142] C. Smith, "Factors associated with specific causes of death amongst HIV-positive individuals in the D:A:D study: the data collection on adverse events of anti-HIV drugs (D:A:D) study group," AIDS, vol. 24, no. 10, pp. 1537-1548, 2010.

[143] L. Waters and C. A. Sabin, "Late HIV presentation: epidemiology, clinical implications and management," Expert Review of Anti-Infective Therapy, vol. 9, no. 10, pp. 877-889, 2011.

[144] C. Mussini, "CD4 cell-monitored treatment interruption in patients with a CD4 cell count $>500 \times 106$ cells/l," AIDS, vol. 19, no. 3, pp. 287-294, 2005.

[145] J. D. Lundgren, "Combination antiretroviral therapy and the risk of myocardial infarction: the data collection on adverse 
events of anti-HIV drugs (DAD) Study Group," New England Journal of Medicine, vol. 349, no. 21, pp. 1993-2003, 2003.

[146] J. V. Baker, W. K. Henry, and J. D. Neaton, “The consequences of HIV infection and antiretroviral therapy use for cardiovascular disease risk: shifting paradigms," Current Opinion in HIV and AIDS, vol. 4, no. 3, pp. 176-182, 2009.

[147] N. Friis-Møller, P. Reiss, C. A. Sabin et al., "Class of antiretroviral drugs and the risk of myocardial infarction," New England Journal of Medicine, vol. 356, no. 17, pp. 17231735, 2007.

[148] A. N. Phillips, J. Neaton, and J. D. Lundgren, "The role of HIV in serious diseases other than AIDS," AIDS, vol. 22, no. 18, pp. 2409-2418, 2008.

[149] R. C. Kaplan, L. A. Kingsley, S. J. Gange et al., "Low CD4 ${ }^{+}$ T-cell count as a major atherosclerosis risk factor in HIVinfected women and men," AIDS, vol. 22, no. 13, pp. 1615$1624,2008$.

[150] H. W. Jaffe, B. L. De Stavola, L. M. Carpenter, K. Porter, and D. R. Cox, "Immune reconstitution and risk of Kaposi sarcoma and non-Hodgkin lymphoma in HIV-infected adults," AIDS, vol. 25, no. 11, pp. 1395-1403, 2011.

[151] J. Bohlius, K. Schmidlin, D. Costagliola, G. Fatkenheuer, M. May, and A. M. Caro-Murillo, "Incidence and risk factors of HIV-related non-Hodgkin's lymphoma in the era of combination antiretroviral therapy: a European multicohort study," Antiviral Therapy, vol. 14, no. 8, pp. 1065-1074, 2009.

[152] E. Zanet, M. Berretta, F. Martellotta et al., "Anal cancer: focus on HIV-positive patients in the HAART era," Current HIV Research, vol. 9, no. 2, pp. 70-81, 2011.

[153] A. D. Monforte, D. Abrams, C. Pradier et al., "HIV-induced immunodeficiency and mortality from AIDS-defining and non-AIDS-defining malignancies," AIDS, vol. 22, no. 16, pp. 2143-2153, 2008.

[154] J. Reekie, C. Kosa, F. Engsig et al., "Relationship between current level of immunodeficiency and non-acquired immunodeficiency syndrome-defining malignancies," Cancer, vol. 116, no. 22, pp. 5306-5315, 2010.

[155] R. K. Heaton, D. B. Clifford, D. R. Franklin et al., "HIVassociated neurocognitive disorders persist in the era of potent antiretroviral therapy: charter Study," Neurology, vol. 75, no. 23, pp. 2087-2096, 2010.

[156] R. J. Ellis, J. Badiee, F. Vaida et al., "CD4 nadir is a predictor of HIV neurocognitive impairment in the era of combination antiretroviral therapy," AIDS, vol. 25, no. 14, pp. 1747-1751, 2011.

[157] J. A. Bartlett, M. J. Fath, R. DeMasi et al., "An updated systematic overview of triple combination therapy in antiretroviral-naive HIV-infected adults," AIDS, vol. 20, no. 16, pp. 2051-2064, 2006.

[158] R. M. Gulick, J. Lalezari, J. Goodrich et al., "Maraviroc for previously treated patients with R5 HIV-1 infection," New England Journal of Medicine, vol. 359, no. 14, pp. 1429-1441, 2008.

[159] T. Wilkin et al., "Maraviroc intensification for suboptimal $\mathrm{CD}^{+}$cell response despite sustained virologic suppression: ACTG 5256," in Proceedings of the 17th Conference on Retrovirus and Opportunistic Infections (CROI '10), abstract 285,2010

[160] T. J. Wilkin, H. R. Ribaudo, A. R. Tenorio, and R. M. Gulick, "The relationship of CCR5 antagonists to CD4 ${ }^{+}$ T-cell gain: a meta-regression of recent clinical trials in treatment-experienced HIV-infected patients," HIV Clinical Trials, vol. 11, no. 6, pp. 351-358, 2010.
[161] R. T. Steigbigel, D. A. Cooper, H. Teppler, J. J. Eron, J. M. Gatell, and P. N. Kumar, "Long-term efficacy and safety of Raltegravir combined with optimized background therapy in treatment-experienced patients with drug-resistant HIV infection: week 96 results of the BENCHMRK 1 and 2 Phase III trials," Clinical Infectious Diseases, vol. 50, no. 4, pp. 605612, 2010.

[162] H. Hatano, T. L. Hayes, V. Dahl et al., "A randomized, controlled trial of raltegravir intensification in antiretroviraltreated, HIV-infected patients with a suboptimal CD4 ${ }^{+} \mathrm{T}$ cell response," Journal of Infectious Diseases, vol. 203, no. 7, pp. 960-968, 2011.

[163] H. Byakwaga, M. Kelly, D. F.J. Purcell et al., "Intensification of antiretroviral therapy with raltegravir or addition of hyperimmune bovine colostrum in HIV-infected patients with suboptimal CD4 ${ }^{+}$T-cell response: a randomized controlled trial," Journal of Infectious Diseases, vol. 204, no. 10, pp. 1532$1540,2011$.

[164] J.-M. Molina, A. LaMarca, J. Andrade-Villanueva et al., "Efficacy and safety of once daily elvitegravir versus twice daily raltegravir in treatment-experienced patients with HIV-1 receiving a ritonavir-boosted protease inhibitor: randomised, double-blind, phase 3, non-inferiority study," The Lancet Infectious Diseases, vol. 12, no. 1, pp. 27-35, 2012.

[165] J. P. Lalezari, K. Henry, M. O’Hearn et al., "Enfuvirtide, an HIV-1 fusion inhibitor, for drug-resistant HIV infection in North and South America," New England Journal of Medicine, vol. 348, no. 22, pp. 2175-2185, 2003.

[166] A. Lazzarin, B. Clotet, D. Cooper et al., "Efficacy of enfuvirtide in patients infected with drug-resistant HIV-1 in Europe and Australia," New England Journal of Medicine, vol. 348, no. 22, pp. 2186-2195, 2003.

[167] V. Joly et al., "Intensification of HAART through the addition of enfuvirtide in naive HIV-infected patients with severe immunosuppression does not improve immunological response: results of a prospective randomised multicenter trial," in Proceedings of the 17th Conference on Retrovirus and Opportunistic Infections (CROI '10), abstract 282, 2010.

[168] S. L. Pett, A. D. Kelleher, and S. Emery, "Role of interleukin2 in patients with HIV infection," Drugs, vol. 70, no. 9, pp. 1115-1130, 2010.

[169] G. Carcelain, P. Saint-Mézard, H. K. Altes et al., "IL-2 therapy and thymic production of naive CD4 T cells in HIV-infected patients with severe CD4 lymphopenia," AIDS, vol. 17, no. 6, pp. 841-850, 2003.

[170] F. Sabbatini, A. Bandera, G. Ferrario et al., "Qualitative immune modulation by interleukin-2 (IL-2) adjuvant therapy in immunological non responder HIV-infected patients," PLoS ONE, vol. 5, no. 11, Article ID e14119, 2010.

[171] G. Marchetti, L. Meroni, S. Varchetta et al., "Low-dose prolonged intermittent interleukin-2 adjuvant therapy: results of a randomized trial among human immunodeficiency virus-positive patients with advanced immune impairment," Journal of Infectious Diseases, vol. 186, no. 5, pp. 606-616, 2002.

[172] C. L. MacKall, T. J. Fry, and R. E. Gress, "Harnessing the biology of IL-7 for therapeutic application," Nature Reviews Immunology, vol. 11, no. 5, pp. 330-342, 2011.

[173] A. Leone, M. Rohankhedkar, A. Okoye et al., "Increased $\mathrm{CD} 4^{+} \mathrm{T}$ cell levels during IL-7 administration of antiretroviral therapy-treated simian immunodeficiency virus-positive macaques are not dependent on strong proliferative responses," Journal of Immunology, vol. 185, no. 3, pp. 16501659,2010 
[174] I. Sereti, R. M. Dunham, J. Spritzler et al., "IL-7 administration drives $\mathrm{T}$ cell-cycle entry and expansion in HIV-1 infection," Blood, vol. 113, no. 25, pp. 6304-6314, 2009.

[175] Y. Levy, C. Lacabaratz, L. Weiss et al., "Enhanced T cell recovery in HIV-1-infected adults through IL-7 treatment," Journal of Clinical Investigation, vol. 119, no. 4, pp. 997-1007, 2009.

[176] C. Sportès, F. T. Hakim, S. A. Memon et al., "Administration of rhIL-7 in humans increases in vivo TCR repertoire diversity by preferential expansion of naive T cell subsets," Journal of Experimental Medicine, vol. 205, no. 7, pp. 17011714, 2008.

[177] S. A. Rosenberg, C. Sportès, M. Ahmadzadeh et al., "IL-7 administration to humans leads to expansion of $\mathrm{CD}^{+}$and $\mathrm{CD} 4^{+}$cells but a relative decrease of CD $4^{+}$T-regulatory cells," Journal of Immunotherapy, vol. 29, no. 3, pp. 313-319, 2006.

[178] Y. Okamoto, D. C. Douek, R. D. McFarland, and R. A. Koup, "Effects of exogenous interleukin-7 on human thymus function," Blood, vol. 99, no. 8, pp. 2851-2858, 2002.

[179] I. Sereti et al., "Recombinant IL-7 expands CD4 T cells in peripheral blood and gut mucosa of chronically HIV-infected immunological non-responder patients," in Proceedings of the 18th Conference on Retrovirus and Opportunistic Infections (CROI '10), abstract 376, 2011.

[180] E. Lugli, Y. M. Mueller, M. G. Lewis, F. Villinger, P. D. Katsikis, and M. Roederer, "IL-15 delays suppression and fails to promote immune reconstitution in virally suppressed chronically SIV-infected macaques," Blood, vol. 118, no. 9, pp. 2520-2529, 2011.

[181] Y. M. Mueller, C. Petrovas, P. M. Bojczuk et al., "Interleukin15 increases effector memory $\mathrm{CD}^{+} \mathrm{T}$ cells and NK cells in simian immunodeficiency virus-infected macaques," Journal of Virology, vol. 79, no. 8, pp. 4877-4885, 2005.

[182] L. J. Picker, E. F. Reed-Inderbitzin, S. I. Hagen et al., "IL15 induces $\mathrm{CD}^{+}$effector memory $\mathrm{T}$ cell production and tissue emigration in nonhuman primates," Journal of Clinical Investigation, vol. 116, no. 6, pp. 1514-1524, 2006.

[183] Y. M. Mueller, D. H. Do, S. R. Altork et al., "IL-15 treatment during acute Simian Immunodeficiency Virus (SIV) infection increases viral set point and accelerates disease progression despite the induction of stronger SIV-specific CD8 ${ }^{+} \mathrm{T}$ cell responses," Journal of Immunology, vol. 180, no. 1, pp. 350-360, 2008.

[184] S. Benedini, I. Terruzzi, A. Lazzarin, and L. Luzi, "Recombinant human growth hormone: rationale for use in the treatment of HIV-associated lipodystrophy," BioDrugs, vol. 22, no. 2, pp. 101-112, 2008.

[185] M. Gelato, M. McNurlan, and E. Freedland, "Role of recombinant human growth hormone in HIV-associated wasting and cachexia: pathophysiology and rationale for treatment," Clinical Therapeutics, vol. 29, no. 11, pp. 2269-2288, 2007.

[186] K. Smith, L. Zheng, R. Bosch et al., "Treatment with recombinant growth hormone is associated with modest improvement in CD4 lymphocyte reconstitution in HIVinfected persons on antiretroviral therapy: results of ACTG A5174," AIDS Research and Human Retroviruses, vol. 26, no. 4, pp. 425-432, 2010.

[187] L. A. Napolitano, D. Schmidt, M. B. Gotway et al., "Growth hormone enhances thymic function in HIV-1infected adults," Journal of Clinical Investigation, vol. 118, no. 3, pp. 1085-1098, 2008.
[188] L. A. Napolitano, J. C. Lo, M. B. Gotway et al., "Increased thymic mass and circulating naive CD4 T cells in HIV-1infected adults treated with growth hormone," AIDS, vol. 16, no. 8, pp. 1103-1111, 2002.

[189] B. R. Hansen, L. Kolte, S. B. Haugaard et al., "Improved thymic index, density and output in HIV-infected patients following low-dose growth hormone therapy: a placebo controlled study," AIDS, vol. 23, no. 16, pp. 2123-2131, 2009.

[190] O. Andersen, B. R. Hansen, W. Troensegaard et al., "Sustained low-dose growth hormone therapy optimizes bioactive insulin-like growth factor-I level and may enhance CD4 Tcell number in HIV infection," Journal of Medical Virology, vol. 82, no. 2, pp. 197-205, 2010.

[191] T. Sivakumar, O. J. Mechanic, D. A. Fehmie, and B. T. Paul, "Growth hormone axis treatments for HIV-associated lipodystrophy: a systematic review of placebo-controlled trials," HIV Medicine, vol. 12, no. 8, pp. 453-462, 2011.

[192] S. Dhillon, "Tesamorelin: a review of its use in the management of HIV-associated lipodystrophy," Drugs, vol. 71, no. 8, pp. 1071-1091, 2011.

[193] Y. Wang, G. Chen, S. Qiao et al., "Keratinocyte growth factor enhanced immune reconstitution in murine allogeneic umbilical cord blood cell transplant," Leukemia and Lymphoma, vol. 52, no. 8, pp. 1556-1566, 2011.

[194] D. Min, A. Panoskaltsis-Mortari, M. Kuro-o, G. A. Holländer, B. R. Blazar, and K. I. Weinberg, "Sustained thymopoiesis and improvement in functional immunity induced by exogenous KGF administration in murine models of aging," Blood, vol. 109, no. 6, pp. 2529-2537, 2007.

[195] R. Seggewiss, K. Loré, F. J. Guenaga et al., "Keratinocyte growth factor augments immune reconstitution after autologous hematopoietic progenitor cell transplantation in rhesus macaques," Blood, vol. 110, no. 1, pp. 441-449, 2007.

[196] R. Rizwan, J. E. Levine, T. Defor et al., "Peritransplant palifermin use and lymphocyte recovery after T-cell replete, matched related allogeneic hematopoietic cell transplantation," American Journal of Hematology, vol. 86, no. 10, pp. 879-882, 2011.

[197] B. R. Blazar, D. J. Weisdorf, T. DeFor et al., "Phase 1/2 randomized, placebo-control trial of palifermin to prevent graftversus-host disease (GVHD) after allogeneic hematopoietic stem cell transplantation (HSCT)," Blood, vol. 108, no. 9, pp. 3216-3222, 2006.

[198] D. Vassilopoulos and L. H. Calabrese, "Risks of immunosuppressive therapies including biologic agents in patients with rheumatic diseases and co-existing chronic viral infections," Current Opinion in Rheumatology, vol. 19, no. 6, pp. 619-625, 2007.

[199] S. F. Plaeger, B. S. Collins, R. Musib, S. G. Deeks, S. Read, and A. Embry, "Immune activation in the pathogenesis of treated chronic HIV disease: a workshop summary," AIDS Research and Human Retroviruses, In press.

[200] J. N. Vermeulen, J. M. Prins, E. Bunnik et al., "Intravenous immunoglobulin (IVIG) treatment for modulation of immune activation in human immunodeficiency virus type 1 infected therapy-naive individuals," AIDS Research and Human Retroviruses, vol. 23, no. 11, pp. 1348-1353, 2007.

[201] A. Lindkvist, A. Edén, M. M. Norström et al., "Reduction of the HIV-1 reservoir in resting $\mathrm{CD} 4^{+} \mathrm{T}$-lymphocytes by high dosage intravenous immunoglobulin treatment: a proof-ofconcept study," AIDS Research and Therapy, vol. 6, article 15, 2009. 
[202] T. Mellberg, V. D. Gonzalez, A. Lindkvist et al., "Rebound of residual plasma viremia after initial decrease following addition of intravenous immunoglobulin to effective antiretroviral treatment of HIV," AIDS Research and Therapy, vol. 8, article 21, 2011.

[203] V. D. Gonzalez, K. Falconer, K. G. Blom et al., "High levels of chronic immune activation in the T-cell compartments of patients coinfected with hepatitis C virus and human immunodeficiency virus type 1 and on highly active antiretroviral therapy are reverted by alpha interferon and ribavirin treatment," Journal of Virology, vol. 83, no. 21, pp. 11407-11411, 2009.

[204] P. W. Hunt, J. N. Martin, E. Sinclair et al., "Valganciclovir reduces $\mathrm{T}$ cell activation in HIV-infected individuals with incomplete $\mathrm{CD} 41^{+} \mathrm{T}$ cell recovery on antiretroviral therapy," Journal of Infectious Diseases, vol. 203, no. 10, pp. 1474-1483, 2011.

[205] P. W. Hunt, "Th17, gut, and HIV: therapeutic implications," Current Opinion in HIV and AIDS, vol. 5, no. 2, pp. 189-193, 2010.

[206] E. Merlini, F. Bai, G. M. Bellistrì, C. Tincati, A. d'Arminio Monforte, and G. Marchetti, "Evidence for polymicrobic flora translocating in peripheral blood of HIV-infected patients with poor immune response to antiretroviral therapy," PLoS ONE, vol. 6, no. 4, article e18580, 2011.

[207] J. M. Brenchley, D. A. Price, T. W. Schacker et al., "Microbial translocation is a cause of systemic immune activation in chronic HIV infection," Nature Medicine, vol. 12, no. 12, pp. 1365-1371, 2006.

[208] W. Jiang, M. M. Lederman, P. Hunt et al., "Plasma levels of bacterial DNA correlate with immune activation and the magnitude of immune restoration in persons with antiretroviral-treated HIV infection," Journal of Infectious Diseases, vol. 199, no. 8, pp. 1177-1185, 2009.

[209] G. Marchetti, G. M. Bellistrì, E. Borghi et al., "Microbial translocation is associated with sustained failure in $\mathrm{CD}^{+}$ T-cell reconstitution in HIV-infected patients on long-term highly active antiretroviral therapy," AIDS, vol. 22, no. 15, pp. 2035-2044, 2008.

[210] R. Hummelen, J. Changalucha, N. L. Butamanya et al., "Effect of 25 weeks probiotic supplementation on immune function of HIV patients," Gut Microbes, vol. 2, no. 2, pp. 80-85, 2011.

[211] F. O. Pettersen, E. A. Torheim, A. E. Dahm et al., "An exploratory trial of cyclooxygenase type 2 inhibitor in HIV-1 infection: downregulated immune activation and improved T cell-dependent vaccine responses," Journal of Virology, vol. 85, no. 13, pp. 6557-6566, 2011.

[212] D. Kvale, V. Ormaasen, A. M. B. Kran et al., "Immune modulatory effects of cyclooxygenase type 2 inhibitors in HIV patients on combination antiretroviral treatment," AIDS, vol. 20, no. 6, pp. 813-820, 2006.

[213] C. C. Johansson, T. Bryn, E. M. Aandahl et al., "Treatment with type-2 selective and non-selective cyclooxygenase inhibitors improves T-cell proliferation in HIV-infected patients on highly active antiretroviral therapy," AIDS, vol. 18, no. 6, pp. 951-952, 2004. 


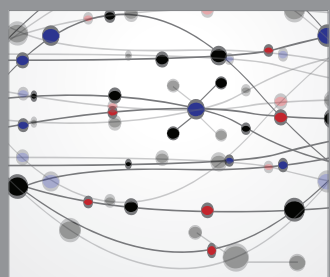

The Scientific World Journal
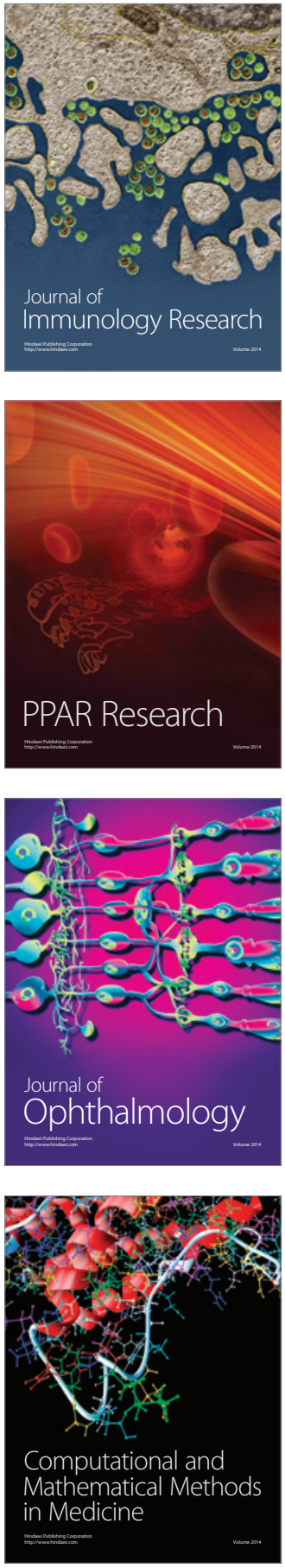

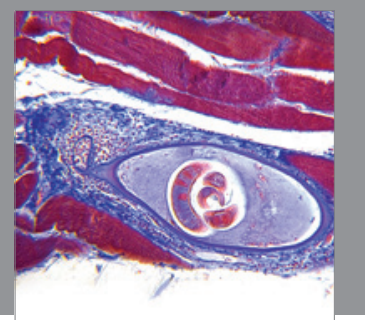

Gastroenterology

Research and Practice
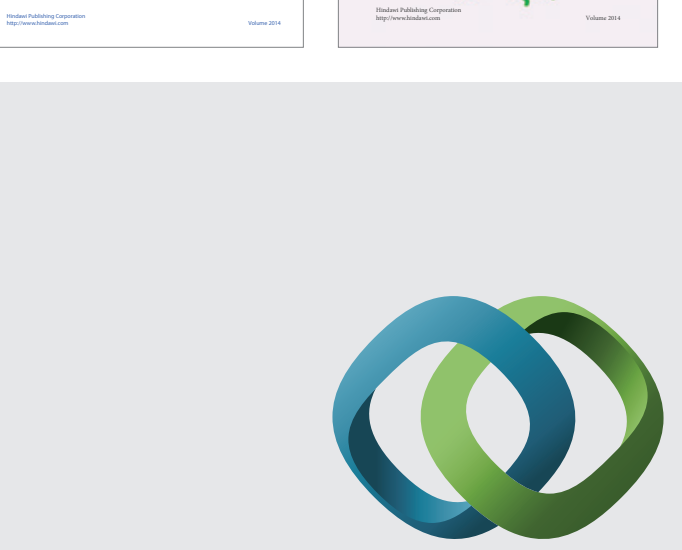

\section{Hindawi}

Submit your manuscripts at

http://www.hindawi.com
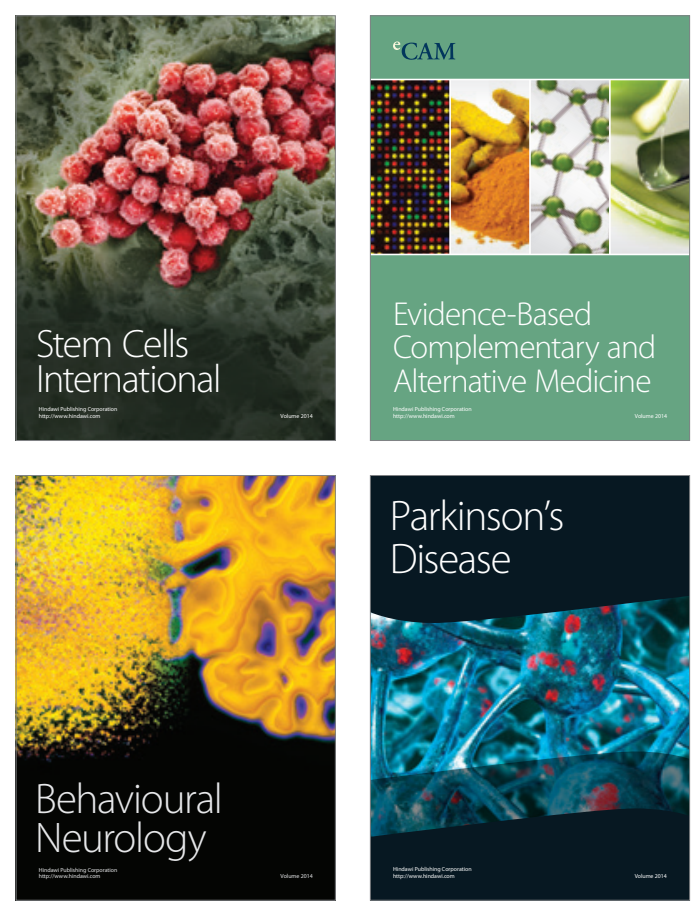

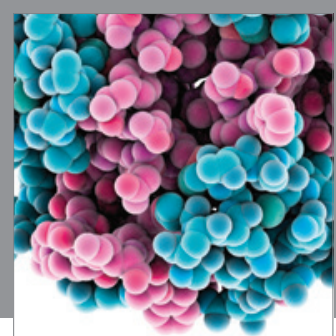

Journal of
Diabetes Research

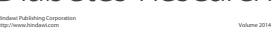

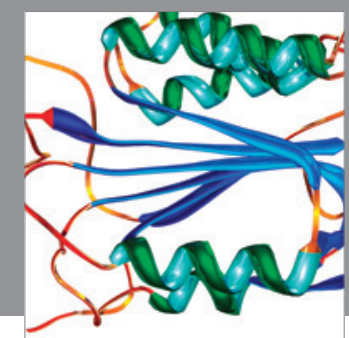

Disease Markers
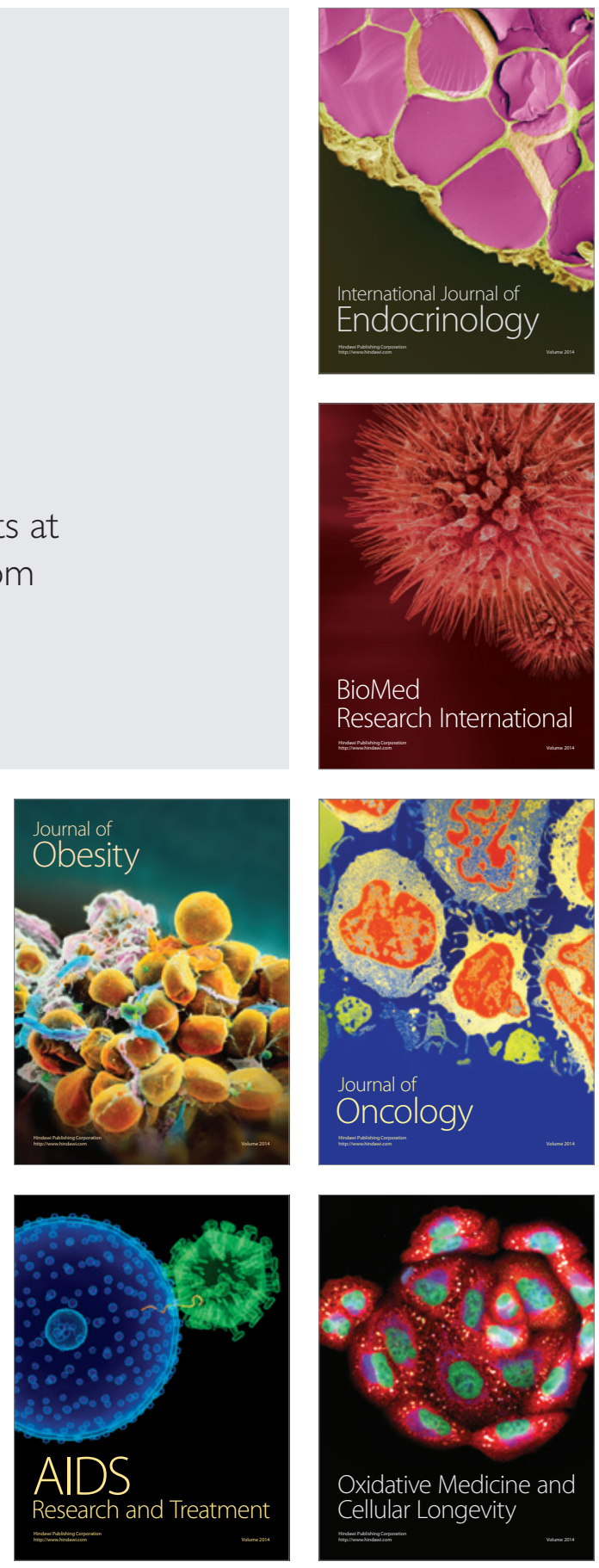